\title{
Skúli SkÚlason
}

\section{Er syndin náttúruleg?}

\section{Um mikilvægi heimsmynda og uppsprettu gilda}

\section{Inngangur}

Vistkerfi jarðar hafa allt frá upphafi tekið stöðugum breytingum sem einkennist ekki síst af próun lífveranna. Náttúran er ekki kyrrstæð. Lífið á jörðinni hefur í gegnum aldirnar staðið frammi fyrir ýmsum ógnum, svo sem eldgosum, ísöldum og fallandi loftsteinum. Samhliða hægfara breytingum hafa miklar og afdrifaríkar sviptingar eða hamfarir átt sér stað. Við lifum slíka tíma. Рað sem er öðruvísi núna, er að ógnin á sér rætur í hegðun mannanna, sem hafa með drottnunarhlutverki sínu, tæknigetu og framkvæmdasemi haft pau áhrif að vistkerfi jarðar eru að umbyltast; lífríkinu hnignar og búsvæði pverra. Pjóðir heims keppast við að ná tökum á loftslagsbreytingum af völdum stjórnlausrar kolefnislosunar okkar síðustu 300 árin. ${ }^{1}$ I ár er jafnframt tekist á við endurskoðun áætlana um viðhald og endurheimt líffræðilegrar fjölbreytni, sem hefur snarminnkað á undanförnum áratugum, en framkvæmd fyrri áætlana hefur að mestu mistekist. ${ }^{2}$ Eins og Andri Snær Magnason rithöfundur útskýrir vel í bók sinni Um tímann og vatnið, erum við að upplifa á eigin ævi, og kynslóðanna sem við umgöngumst, breytingar á vistkerfum og lífsskilyrðum sem flestir sjá fyrir sér sem hæga jarðsögulega ferla. ${ }^{3}$ Auk pess hafa vísindamenn fært sannfærandi rök

1 Sjá meðal annars vefsíðu Sameinuðu pjóðanna um loftslagsbreytingar: bttps://unfccc. int/, og upplýsingar um Loftslagsráð íslenskra stjórnvalda: bttps://loftslagsrad.is/.

2 IPBES, Global Biodiversity Assessment 2019, Global Biodiversity Outlook 5, sótt 7. desember 2020 af https://www.cbd.int/gbo5; og „Líffræðileg fjölbreytni“, Stjórnarrád Íslands, sótt 7. desember 2020 af https://www.stjornarradid.is/verkefni/umhverfiog-natturuvernd/natturuvernd/liffraedileg-fjolbreytni/.

3 Andri Snær Magnason, Um tímann og vatnið, Reykjavík: Mál og menning, 2019; sjá

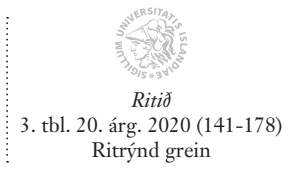

(C) 2020 Ritið, tímarit Hugvísindastofnunar og höfundur greinarinnar

Útgefandi:

Hugvísindastofnun Háskóla Íslands, Sæmundargötu 2, 102 Reykjavík
Birtist á vefnum http://www.ritid.hi.is. Tengiliður: ritið@hi.is

DOI: 10.33112/ritid.20.3.7

Birt samkvæmt skilmálum Creative Commons BY (4.0). 
fyrir að yfirstandandi heimsfaraldur Covid-19 kórónuveirunnar megi rekja til taumlausrar ágengni, óvarkárni og hugsunarleysis í samskiptum okkar við vistkerfi jarðar og umhverfið. ${ }^{4}$ Félagsleg staða einstaklinga og pjóða er einnig birtingarmynd umhverfisvandans, par sem alls kyns gróft misrétti viðgengst, einstaklings- og neysluhyggja grasserar, græðgi ræður för, stríð geisa og mikill fjöldi fólks er á flótta. Síðast en ekki síst sjáum við uppgang popúlískra öfgasjónarmiða sem ógna frelsinu og lýðræðinu.

Eitthvað mikið hefur farið úrskeiðis og margir óttast petta ástand eins og stóraukin umræða um umhverfismál undanfarin misseri - meðal annars í fjölmiðum - ber með sér. ${ }^{5}$ Pessi umræða snertir alla. Börn og ungmenni mótmæla loftslagsbreytingum, stjórnmálamenn takast á um mögulegar lausnir, fræði- og listamenn keppast við að miðla sýn og pekkingu um mann og umhverfi, náttúruvísindamenn leita bæði skamm- og langtímalausna - oftar en ekki tæknilegra - til að takast á við ástandið og fjölskyldur og skólakerfið reyna að leggja sitt af mörkum til að upplýsa um hlutina og hafa pannig áhrif á hegðunina. Pessi viðleitni endurspeglar góðan vilja til að bæta heiminn og fjölmargar leiðir virðast vænlegar til árangurs. Sjálfbær próun í umgengni og nýtingu auðlinda náttúrunnar er ofarlega á baugi og gjarnan er litið til fortíðar um mögulegar lausnir, til dæmis á landbúnað fyrri tíma og afstöðu sumra frumbyggjasamfélaga til náttúrunnar. Viljinn til að gera betur og að láta verkin tala er svo sannarlega fyrir hendi. Раð sést vel á afgerandi viðbrögðum heimsins við Covid-19 faraldrinum par sem um er að ræða beina ógn við líf og heilsu okkar mannanna hér og nú. Eðlilegt er að fólk spyrji hvers vegna viðbrögðin við loftslagsbreytingum og hruni líffræðilegrar fjölbreytni sem augljóslega ógna ekki síður

líka nýja kvikmynd: David Attenborough. Life on our Planet, leikstjórar Alastair Fothergill, Jonathan Hughes og Keith Scholey, Netflix, 2020.

4 Bergljót Baldursdóttir, „Hægt að koma í veg fyrir heimsfaraldra eins og COVID-19“, $R U ́ V, 19$. ágúst 2020, sótt 7. desember 2020 af https://www.ruv.is/frett/2020/08/19/ baegt-ad-koma-i-veg-fyrir-heimsfaraldra-eins-og-covid-19; og Andrew P. Dobson, Stuart L. Pimm, Lee Hannah, Les Kaufman, Jorge A. Ahumada, Amy W. Ando, Aaron Bernstein, Jonah Busch, Peter Daszak, Jens Engelmann, Margaret F. Kinnaird, Binbin V. Li, Ted Loch-Temzelides, Thomas Lovejoy, Katarzyna Nowak, Patrick R. Roehrdanz, Mariana M. Vale, „Ecology and economics for pandemic prevention. Investments to prevent tropical deforestation and to limit wildlife trade will protect against future zoonosis outbreaks“, Science 369/2020, bls. 379-381.

5 Mjög gott dæmi eru sjónvarpspættir Ríkisútvarpsins á síðasta ári um stöðuna í umhverfismálum, Hvað höfum við gert? (2019). Nú er unnið að framhaldspáttaröðinni Hvað getum við gert? 
tilveru okkar eru ekki álíka öflug. ${ }^{6}$ Pessu mætti velta fyrir sér en hér verður staldrað við eitt atriði sem oft ber á góma og brýnt er að veita mun meiri athygli einmitt núna. Ljóst er að prátt fyrir góðan hug, vilja og viðleitni er eins og einhver hulinn kraftur togi okkur í pann skaðlega farveg sem við erum augljóslega stödd $\mathbf{i}^{7}$.

Svo virðist sem pessi kraftur eigi sér rætur í peirri heimsmynd nútímamannsins sem lýsir sér í pví að náttúran sé sett til hliðar og maðurinn sé ekki partur af henni. Athyglin beinist pá að pröngum hagsmunum hans. ${ }^{8}$ Heimsmynd hvers og eins okkar mótar vissulega hugarfarið, hugsunina, pekkinguna og getuna til að breyta rétt. Við erum mörg sammála um að mannkynið parf að breyta hegðun sinni, pó ekki væri nema til að poka sjálfbærri próun áfram í von um betri framtíðarsýn. Hér er greinilega um risastórt verkefni að ræða en jafnframt pað mikilvægasta sem við stöndum frammi fyrir. Petta gefur tilefni til skoðunar á hinni siðferðilegu hlið viðfangsefnisins, sem krefst athugunar á peim gildum eða verðmætum lífsins

6 Sleðaháttur gagnvart loftslagsmálum er meðal annars ræddur í nýlegri grein tímaritsins Nature, sjá Jeff Tollefson, „Can the world slow global warming?", Nature 573/2020, bls. 324-326. Áríðandi rannsóknir og verkefni tengd loftslagsbreytingum hafa einnig truflast vegna peirrar athygli sem Covid-19 faraldurinn tekur, sjá „United in Science report. Climate Change has not stopped for COVID19“, World Meteorological Organization, 9. september 2020, sótt 9. desember af https://public. wmo.int/en/media/press-release/united-science-report-climate-change-has-notstopped-covid19; áhugavert er að skoða hvernig faraldurinn hefur, að minnsta kosti, pegar aðgerðir voru hvað harðastar, skilað sér í minni losun gróðurhúsalofttegunda, sjá: „Sögulegur samdráttur í losun dugar ekki til“, Veðurstofa Íslands, 9. september 2020, sótt 9. desember 2020 af https://www.vedur.is/um-vi/frettir/sogulegur-samdrattur-i-losun-dugar-ekki-til? fbclid=IwAR2 cc4g6uspgHYkKtFRfmMP99QsYHqeFcDaL1uqxnilL58RBuuD8gV1xjUM.

7 Sjá áhugaverða umfjöllun sem tengist pessu í Guðni Elísson, „Рið munuð öll deyja! Lita dómsdagsspár hugmyndir manna um loftslagsvísindi? “, Morgunblaðið 19. apríl 2008, bls. 8-9; og Guðni Elísson, „Dómsdagsklukkan tifar. Upplýsing og afneitun í umræðu um loftslagsbreytingar", Ritið 1/2011, bls. 91-136.

8 Hér má benda á ýmsar heimildir, til dæmis eftirfarandi efni sem ég vísa enn frekar til síðar í greininni: Wendy Wheeler, The Whole Creature. Complexity, Biosemiotics and the Evolution of Culture, London: Lawrence \& Wishart, 2006; Náttúran í ljósaskiptипит, ritstjóri Björn Porsteinsson, Reykjavík: Heimspekistofnun - Háskólaútgáfan, 2016; Guðbjörg R. Jóhannesdóttir og Porvarður Árnason, „Inngangur að pema“, Ritið 3/2019, bls. 1-8; Jón Ásgeir Kalmansson, „„Hið panda segl, hinn rennandi lækur ...". Athygli, ást og lotning í siðfræði náttúrunnar“, Ritið 3/2019, bls. 69-94; sjá líka fyrrnefnda heimildamynd David Attenborough. Life on our Planet; einnig skal bent á eftirfarandi bók sem dregur fram sannfærandi mynd af manninum sem náttúruveru: David Abram, The Spell of the Sensuous, New York: Vintage Books Editions, 1997. 
sem gera pað pess virði að pví sé lifað. Petta er líf par sem leitast er við að vera í ásættanlegu samræmi við líf annarra lífvera og vistkerfi jarðar. Kannski eru pað einmitt viðhorfin til slíkra gilda og verðmæta, og í kjölfarið raunhæfur skilningur á peim og uppsprettu peirra, sem eru forsenda og möguleg leiðsögn til að breyta heimsmynd okkar og atferli. Breytni okkar, meðal annars gagnvart vistkerfum jarðar endurspeglar breyskleika og skammsýni; skaðlegt framferði og rof gagnvart uppsprettu gilda lífsins í náttúrunni sem teygir rætur sínar til tilveru okkar, vitundar og hugsunar. Раð er í skilningi breyskleikans sem skilgreina má petta rof sem synd sem lítilsvirðir pau gildi sem náttúran felur í sér.?

Hér verður fjallað um petta viðfangsefni frá víðu sjónarhorni, í senn sögulega, heimspekilega og líffræðilega. Fyrst verða raktar stuttlega ákveðnar hugmyndasögulegar forsendur pess vanda sem við erum í og sem greina sérstaklega frá afdrifaríkum hlut vísindanna í pví ferli. Pví næst verður vikið að eðli og uppruna gilda ${ }^{10}$ í náttúrunni, og par beitt meðal annars heimspekilegum, sem og vist- og próunarfræðilegum nálgunum með áherslu á vistkerfi. Pví verður haldið fram að mannlífið sé órofa tengt pessum margbrotnu gildum ásamt öllum peim fjölbreyttu lífverum og vistkerfum sem við byggjum jörðina með. Tilurð gilda, túlkun og beiting peirra í vistkerfum jarðar er í peirri greiningu alfarið á forsendum náttúr-

Greinin er byggð á málpingi um syndina par sem pessi mál voru rædd í pví samhengi. Okkur er tamt að sjá syndina fyrst og fremst í trúarlegu ljósi. Pað er vel skiljanlegt í ljósi stöðu syndahugtaksins í trúarlegum hugmyndum. Eins og margar aðrar stofnanir samfélagsins hefur kirkjan tekið afgerandi afstöðu til umhverfismála, sjá til dæmis yfirlýsingu Francis páfa um loftslagsmál, „Pope Francis calls for action to tackle climate change linking its impacts to poverty, inequality \& social injustice“, Business \& Human Rights Research Centre, 18. júní 2015, sótt 9. desember 2020 af https://www.business-humanrights.org/en/pope-francis-calls-for-action-totackle-climate-change-linking-its-impacts-to-poverty-inequality-social-injustice; og „Prestastefna 2018 - Ályktun frá umhverfishópi Pjóðkirkjunnar“, Pjóðkirkjan, 26. apríl 2018, sótt 9. desember af https://kirkjan.is/kirkjan/graen-kirkja/alyktunprestastefnu/; alheimsráðstefnu trúfélaga sem haldin var í október 2020, „Faith for Nature - Multi-Faith Action“, Faith for Nature, sótt 9. desember 2020 af http//www. faithfornature.org; og nýlega bók um kristna siðfræði og loftslagsbreytingar: Sólveig Anna Bóasdóttir, Guð og gróðurbúsaábrif. Kristin siðfreði á tímum loftslagsbreytinga, Reykjavík: Háskólaútgáfan, 2017; og nýlega frétt Ríkisútvarpsins um skilaboð Dalai Lama andlegs leiðtoga Tíbeta til stjórnmálamanna heimsins um tækifæri til að beina sjónum enn frekar að hnattrænni hlýnun, Markús P. Pórhallsson, „Dali Lama segir lag að bregðast við hnattrænni hlýnun“, $R U ́ V, 12$. september 2020, sótt 7. desember 2020 af https://www.ruv.is/frett/2020/09/12/dalai-lama-segir-lag-ad-bregdast-vidhnattraenni-hlynun.

10 Hugtakið gildi á sér samsvörun í hugtakinu verðmæti (e. value). 
unnar og pví má í peim skilningi komast að peirri niðurstöðu að syndin sé sannarlega náttúruleg, pví pað er gagnvart pessum gildum sem hugarfarsog hegðunarleg af-tenging okkar við náttúruna er skaðlegust. Í pessu felst heildræn sýn á náttúruna par sem síbreytileg framvinda varðar alla lífræna starfsemi, jafnt рað sem okkur er tamt að nefna vitund okkar og skynsemi, pað sem okkur er meira hulið en varðar líkama okkar og annarra lífvera, sem og vistkerfin og lífheiminn í heild. Pannig er dregið verulega úr peim greinarmun sem við gjarnan gerum á pekkingu sem við tengjum einhvers konar „vitund“ (og eignum gjarnan manninum) og allri annarri pekkingu sem felst í peim margbrotnu ferlum og kerfum sem eru til staðar í náttúrunni. Við vitum meira en við getum tjáð okkur um. ${ }^{11}$ Að lokum verður bent á mikilvægi pess að við lögum hegðun okkar að heildrænni sýn á stöðu okkar í náttúrunni og nýtum okkur pekkingu á pessu sviði í hvers kyns stefnumótun og ákvarðanatöku um málefni náttúrunnar. Lykilskref á peirri vegferð er að auka enn frekar umræðu, menntun og pekkingu á uppsprettu merkingar og gilda sem leið til að styrkja gagnrýna skapandi hugsun. Slík hugsun er ein mikilvægasta forsenda pess að breyta ríkjandi heimsmynd, sem stillir manninum upp andspænis náttúrunni, pannig að samfélög geti próast til betri vegar.

\section{Maðurinn sem bluti náttúrunnar - eða bvað?}

Jónas Hallgrímson lýsti náttúrunni sem „birtingarmynd allra hluta og peirra afla sem ráða gerð peirra og hegðun“. ${ }^{12}$ Pessi skilgreining er í samræmi við heildstæða sýn, par sem náttúran er í raun allur veruleikinn eða heimurinn. Hinar fjölmörgu hugmyndir mannsins um heiminn í gegnum tíðina greina hann á margvíslegan hátt, allt frá pví að vera samsettan úr margs konar einingum sem saman mynda einhvers konar heildarkerfi, yfir í að sjá heiminn alfarið sem heildrænt ferli í sífelldri framvindu. Svona hugmyndir má sjá í heimspeki Forn-Grikkja sem varð grunnur vestrænnar heimspeki ${ }^{13}$ sem og í austrænni heimspeki sem á sér langa sögu í beim

11 Hér væri ef til vill nákvæmari framsetning að segja: að við vitum meira en við vitum að við vitum. Pessi framsetning tengist hugmyndum um falda pekkingu (e. tacit knowledge), og er höfð eftir Michael Polanyi pegar hann skrifar „....we know more than we can tell“", sjá Wendy Wheeler, The Whole Creature, bls. 61.

12 Sjá Páll Skúlason, Náttúrupalingar, Reykjavík: Háskólaútgáfan, 2014, bls. 44, par sem einnig er vísað til frumheimildar. Páll nýtti sér skilgreiningu Jónasar mikið í sinni náttúruheimspeki.

13 Sjá gott yfirlit í John Dupré og Daniel J. Nicholson, „A Manifesto for a Processual 
heimshluta. ${ }^{14}$ Í pessum hugmyndakerfum er maðurinn oft hugsaður sem náttúruvera og órofa hluti af náttúrunni, en ósjaldan leggja hugmyndirnar áherslu á sérstöðu mannsins í náttúrunni, til dæmis sem andlegrar vitsmunaveru. Í okkar samfélagi er gjarnan bent á sköpunarsöguna í fyrstu Mósebók sem dæmi um nokkuð afgerandi mannhverfa sýn, en hún dregur manninn fram sem drottnara jarðar og greinilega aðskilinn frá öðrum lífverum. Á endurreisnartímanum og svo upplýsingaöldinni (um pað bil 1500-1750) koma fram margs konar kenningar sem varða stöðu mannsins í náttúrunni og hvernig menn kusu að sjá eðli og samsetningu náttúrunnar í heild. Pessi atburðarás tengdist uppruna nútímavísinda, og lagði pannig grunninn að peirri viðamiklu pekkingu sem við nú búum yfir og birtist ekki hvað síst í margvíslegri tækni sem hefur umbreytt og iðnvætt samfélög okkar. Sú umbreyting hefur stuðlað að velmegun sumra en um leið hörmungum annarra, og er jafnframt ein af rótum pess mikla umhverfisvanda sem mannkynið stendur frammi fyrir.

Ekki er sanngjarnt að kenna tilkomu vísinda sem hugmyndakerfis einum um pessi vandamál nútímans. Orsök peirra má frekar rekja til hugmyndafræðilegra átaka sem koma meðal annars fram á upplýsingaöldinni, hafa magnast allt fram á pennan dag, og hafa vissulega skapað ákveðna sögulega umgjörð um próun vísinda og tækni. Pessi átök eru á milli peirra hugmynda, að annars vegar starfi náttúran eins og vél, par sem öfl og lögmál eðlisfræðinnar ráði helst ferðinni og best sé að rannsaka hana sem slíka, og hins vegar að náttúran einkennist ekki síður af síkvikri samvirkni og framvindu, par sem hinn lifandi hluti hennar feli í sér markmið, gildi og tilgang sem verði að taka með í reikninginn ef gagnlegur skilningur á að fást. ${ }^{15}$ Pessi ágreiningur kann að hljóma einkennilega, sérstaklega pegar hugað er að próun í lífríkinu, par sem samskipti og kerfi fela augljóslega í sér merkingarbæra framvindu og áætlanir, ekki síst ef við lítum til mannlífsins. En svona er petta nú samt og leikar standa harla ójafnt. Pó ýmis merki séu um aukna skynsamlega samræðu fræðimanna um pennan ágreining einkennist staðan í dag af sjónarmiðum vélhyggjunnar og fylgifiskum hennar, svo sem tilhneigingu til að einfalda og smætta veruleikann, sem og mikilli áherslu á sértæka eiginleika hluta og ákveðna einstaklingshyggju, sem oftar en ekki

Philosophy of Biology“, Everything Flows. Towards a Processual Philosophy of Biology, ritstjórar Daniel J. Nicholson og John Dupré, Oxford: Oxford University Press, 2018, bls. 5-7.

14 Sjá umfjöllun í ritgerðum í Náttúran í ljósaskiptunum.

15 Fjallað verður nánar um pessa hugsun síðar í greininni. 
setur prönga og tímabundna hagsmuni mannsins í öndvegi. ${ }^{16}$

Vélhyggjan er gjarnan tengd við hinn fræga franska heimspeking René Descartes (1596-1650) sem hafði mikil áhrif á próun heimspeki og vísinda síns tíma en andi hans hefur svifið yfir vötnum til okkar daga. Descartes lýsti náttúrunni sem vél: „Ég hef lýst pessari jörð, og í raun heiminum öllum, eins og hún væri vél: Ég hef einungis haft í huga ólíka lögun og ólíkar hreyfingar hluta hennar." ${ }^{17}$ Einn hluti pessarar kenningar, sem hann er hvað pekktastur fyrir, er að aðgreina manninn frá dýrum sem handhafa hugsunar, sálar og tilfinninga, meðan aðrar lífverur séu eingöngu sálarlausar vélar (f. Bêtes machines) $)^{18}$, og pví til frekari áréttingar segir Descartes: „Fjöldi og skipulag tauga, æða, beina og annarra hluta dýrs gefur ekki til kynna að náttúrunni sé ekki fært að skapa pau, ef gert er ráð fyrir að allt í náttúrunni fylgi vélgengum lögmálum." ${ }^{19}$ Pessi afgerandi vélhyggja og tvíhyggjan um aðskilnað sálar og líkama, hugsunar og vitundar manna frá öðrum lífverum, og strangt til tekið öðrum náttúrufyrirbærum, hafði mikil áhrif á hugmyndir fólks, og endurspeglast greinilega í nútímanum..$^{20}$

16 Eftirfarandi bækur veita góða kynningu og umfjöllun um petta: Wendy Wheeler, The Whole Creature. Complexity, Biosemiotics and the Evolution of Culture, 2006; Beyond Mechanisms. Putting Life Back to Biology, ritstjórar Brian G. Hennig og Adam C. Scarfe, Plymouth UK: Lexington Books, 2013; Denis M. Walsh, Organisms, Agency, and Evolution, Cambridge: Cambridge University Press, 2015. Sjá líka góða umfjöllun í grein Jóns Ásgeirs Kalmanssonar, „„Hiðð panda segl, hinn rennandi lækur ..."“, bls. 69-94.

17 „I have described this earth, and indeed the whole universe, as if it were a machine: I have considered only the various shapes and movements of its parts“, D. M. Walsh, Organisms, Agency, and Evolution, bls. 8. (Úr René Descartes, Principia Philosophiae (1647), úr Selected Philosophical Works, ritstjórar John Cottingham, Robert Stoothoff og Dugald Murdoch, Cambridge: Cambridge University Press, 1985, bls. 198). Greinarhöfundur býðir.

18 Sama rit, bls. 8.

19 "The number and the orderly arrangement of the nerves, veins, bones and other parts of an animal do not show that nature is insufficient to form them, provided that you suppose that in everything nature acts in accordance with the laws of mechanics." Sama rit, bls. 8. (Úr René Descartes, Principia Philosophiae (1647), Escerpted from Selected Works, ritstjórar Cottingham, Robert Stoothoff og Dugald Murdoch, Cambridge: Cambridge University Press, 1985, bls. 198). Greinarhöfundur pýðir.

20 Sjá til dæmis Wendy Wheeler, The Whole Creature. Complexity, Biosemiotics and the Evolution of Culture, 2006 og Jón Ásgeir Kalmansson, „„,Hið panda segl, hinn rennandi lækur ...““, bls. 69-94. Pessi afstaða einkennist gjarnan af pví að einingar, einstaka hlutir, eða „sjálf“ njóta forgangs í hugmyndum og eru gjarnan látin búa yfir einhvers konar sjálfvirkni, samanber algenga orðræðu um sjálfstæða starfsemi erfðaefnisins (DNA), sjá umfjöllun um petta vandamál í Richard Lewontin, The Triple 
Hugsunin styður við pá staðreynd að við lítum gjarnan á okkur sem drottnara náttúrunnar, og fullyrða má að umgengni okkar í henni, nýting náttúruauðlinda og viðleitni til að stjórna náttúrufyrirbærum - til dæmis svokölluðum meindýrum (sérstaklega í landbúnaði) - ber pess skýr merki að við trúum á vélrænar og einfaldar tæknilegar lausnir flókinna vistfræðilegra verkefna. Pessar „lausnir“ hafa oftar en ekki valdið ómældum skaða, svo sem ofveiði, útrýmingu stofna og tegunda, óafturkræfum vistkerfislegum breytingum, hruni vistkerfa og gríðarlegri mengun. Og bað sem meira er, hugsun okkar, samskipti, áætlanagerð og tungumál eru mörkuð af drottnunarsýn. Pannig tölum við til dæmis gjarnan um mann og náttúru. Orðræðan í samfélaginu - og par af leiðandi hugsunin, stefnuplögg, áætlanagerðir, lög, reglugerðir og kennsluefni - mótast af ofangreindri sýn, sem lýsa má sem pröngri mannhverfri afstöðu sem aðskilur mann og náttúru. ${ }^{21}$ Hér kemur við sögu hinn huldi kraftur sem áður hefur verið nefndur; við eigum hreinlega erfitt með að tala og skrifa um pessi mál (par með talið að benda á vandann og aðrar leiðir til að skoða náttúruna) öðruvísi en að framsetningin, orðin, hugtökin og setningarnar séu togaðar í átt að ríkjandi vél- og tvíhyggju um mann og náttúru sem eru í orðsins fyllstu merkingu greypt inn í hvert okkar, samfélagið og menninguna. Nú er hvorki rétt né sanngjarnt að eigna Descartes alfarið að svona er komið, margt fleira mætti draga fram sem varðar hugsunina, vísindabyltinguna, samfélagsgerðina, iðn- og tæknivæðingu, valdakerfi pjóða, stjórnmálakenningar og svo framvegis, sem hefur einkennt próun mála eftir hans daga. ${ }^{22}$

\section{Vélhyggja og siðferði}

En hver er pessi siðferðilega hlið? Lítum fyrst á dæmi sem varðar dýr og skýrir alvarleika vandans. Descartes sagði dýrin sálarlausar vélar, og par af leiðandi tilfinningalaus. Svona afstaða réttlætti meðal annars hrottafengna meðhöndlun manna á öðrum dýrum, til dæmis í vísindalegum tilraunum. ${ }^{23}$

Helix. Gene, Organism and Environment, Cambridge MA: Harvard University Press, 2000.

21 Nú blasir við að afstaða manns er í eðli sínu háð pví hver við erum, og ég legg pví áherslu á að í pessari ritgerð vísar notkun hugtaksins „mannhverfni“ til afstöðu sem einkennist af pröngum sjónarmiðum og hagsmunum.

22 Eftirfarandi bók gerir pað mjög vel: Ársæll Már Arnarsson, Siðustu ár sálarinnar, Reykjavík: Háskólaútgáfan, 2016.

23 Eftirfarandi grein gefur prýðilegt yfirlit á pessari sögu: Rita Leal Paixão og Fermin Roland Schramm, „Ethics and animal experimentation: what is debated?", Cad. Saúde Pública 1999, bls. 99-110. 
Hugsum um framkomu manna við dýr nú á tímum. Margt hefur vissulega áunnist, en samhliða góðri stefnu margra um að bera virðingu fyrir dýrum og jafnvel öllu sem hrærist, er málum frekar illa komið. Pannig eru til dæmis kenningar um tilfinningar og sársaukaskyn dýra enn mjög á reiki og augljóslega markaðar af pröngum mannhverfum sjónarmiðum og vélhyggjuvísindum. Til að mynda flokkum við dýr með ákveðnum hætti í merkileg dýr, ómerkileg og oft óæskileg. ${ }^{24}$ Pau síðastnefndu eru gjarnan réttdræp og með hvaða aðferðum sem hentugar pykja. Gott dæmi um stöðu mála er að í heimi líffræðinnar er ennpá deilt um hvort fiskar finni til. ${ }^{25}$ Раð er eins og einhvers konar sljóleiki - jafnvel hrein afneitun - gagnvart siðferðilegum gildum tilverunnar hafi fest rætur. Og pað eru sambærileg siðferðileg afglöp sem tengjast hlut okkar í stóru umhverfisvandamálunum, svo sem loftslagsbreytingum og hruni líffræðilegrar fjölbreytni. Siðferðilegi sljóleikinn nær sem sagt einnig til skilnings okkar á mikilvægi gilda lífsins í kerfum og ferlum náttúrunnar í heild.

Með pví að líta á náttúruna sem vél sem við mennirnir stöndum til hliðar við, sem einu lífverurnar gæddar sál, tilfinningum og hugsun - 1́ raun eiginlegu lífi, hefur okkur tekist að fjarlægja, eða draga verulega úr, siðferðilegum gildum og tengdum verðmætum frá náttúrunni í menningu okkar, og gefið okkur sem einstaklingum og samfélögum sjálfskipaðan rétt til að skilgreina slík gildi og verðmæti einhliða út frá okkur sjálfum, sem pá oftar en ekki takmarkast við afmarkaðar parfir og langanir. Hér hefur náttúran verið afsiðuð. Hugtakið afsiðun felur í sér að ekki er borin virðing fyrir peim gildum sem náttúran býr yfir, og hún er pví utan pess umráðasviðs sem ákvarðar siðferðilega breytni. Jón Ásgeir Kalmansson gerir góða grein fyrir pessu vandamáli í grein sinni „„Hið panda segl, hinn rennandi lækur ...““”, pegar hann ræðir prönga - en vissulega útbreidda - mannhverfa afstöðu í skrifum Porsteins Hilmarssonar heimspekings, sem heldur pví fram að sérstæðir eigin-

24 Eftirfarandi grein veitir áhugaverða innsýn í viðhorf til dýra: Shauna Laurel Jones, Edda R. H. Waage og Karl Benediktsson, „Himnesk rödd en helvískur andi? Um friðun álftar á Íslandi og nýlega árekstra álfta og kornbænda“, Ritið 3/2019, bls. 9-44; einnig er góð umfjöllun í nýlegu hefti Ritsins sem helgað var sambandi fólks og dýra: Katla Kjartansdóttir og Kristinn Schram (pemaritstjórar), „Náttúruhvörf: Samband fólks og dýra“, Ritið 1/2020.

25 Sjá til dæmis fyrirlestur dr. Victoriu Braithwaite sem var sérfræðingur á pessu sviði: „Do fish feel pain and why does it matter?“, Youtube, 27. nóvember 2016, sótt 7. desember 2020 af https://www.youtube.com/watch?v=cyjHHmc7QB0; og eftirfarandi greinar: Culum Brown, „Fish intelligence, sentience and ethics“, Animal Cognition 2015, bls. 1-17; og Lynne U. Sneddon og Matthew C. Leach, „Anthropomorphic denial of fish pain“, Animal Sentience 2016, bls. 1-3. 
leikar mannsins geri hann að handhafa alls gildismats og siðferðis, par sem náttúran er að öllu leyti réttlaus. Í sömu grein fjallar Jón Ásgeir um sýn og kenningar Aldo Leopolds (1817-1862) og Henrys Davids Thoreaus (18871948), par sem siðferðileg gildi lands, vistkerfis og náttúrunnar allrar eru höfð í hávegum. ${ }^{26}$

\section{Visindi og afsiðun náttúrunnar}

Óhætt er að segja að afsiðun náttúrunnar komi greinilega fram í fræðaheiminum, hvernig við öflum, varðveitum og miðlum pekkingu. Einfalt dæmi er aðskilnaður hug- og félagsvísinda annars vegar og náttúruvísinda hins vegar. Hug- og félagsvísindin takast meðal annars á við sögu, tungumál, samfélög manna, trúmál, heimspeki, siðfræði, sálfræði og stjórnmál, á meðan náttúruvísindin, svo sem eðlisfræði, efnafræði, líffræði og tæknigreinar eins og verkfræði og læknisfræði, skoða gangverk náttúrunnar oftast á afmarkaðan hátt, gjarnan með vélrænum smættunaraðferðum, til dæmis mannslíkamann, samfélög lífvera og vistkerfi. ${ }^{27}$ Hug- og félagsvísindi, par með talið heimspeki (sem skipuleg fræðigrein), hafa ekki verið undanskilin áhrifum vélhyggjunnar, par sem mikilvægi abstrakt hlutlægrar nálgunar, par sem smættun og eigingildi hlutanna (til dæmis einhliða mikilvægi einstaklingsins eða sjálfsins) eru í öndvegi. ${ }^{28}$ Svokallaður pósitívismi í mál- og

26 Jón Ásgeir Kalmansson, „„,Hið panda segl, hinn rennandi lækur ...““, bls. 69-94; og Porsteinn Hilmarsson, „Pekking og siðferði í umgengni við náttúruna“, Náttúrusýn, ritstjórar Róbert H. Haraldsson og Porvarður Árnason, Reykjavík: Rannsóknarstofnun í siðfræði, 1994, bls. 105-110.

27 Vélhyggja í náttúruvísindum skín í gegn hvert sem litið er. Sem dæmi af nýlegri reynslu höfundar hlustaði ég á yfirlitsfyrirlestur pekkts erlends fræðimans, á ráðstefnu norræna vistfræðifélagsins OIKOS, sem haldin var í Reykjavík fyrr á pessu ári par sem fyrirlesarinn líkti vistkerfi við klukku og verkefnið snerist um að greina sundur einstaka hluta „klukkunnar“ og átta sig á hvernig peir virkuðu hver á annan. Samlíking á náttúrulegum kerfum við starf klukku er algeng og hentar auðvitað einkar vel í hugmyndaheimi vélhyggjunnar, sjá Richard Lewontin, The Triple Helix. Gene, Organism and Environment, 71-72. Sjá einnig umfjöllun um vandann sem fylgir aðgreiningu sérhæfðra fræðigreina í umfjöllun um náttúruna í eftirfarandi greinum: Ólafur Páll Jónsson, „Maður og náttúra“, Náttúran i ljósaskiptunum, ritstjóri Björn Porsteinsson, Reykjavík: Heimspekistofnun - Háskólaútgáfan, 2016, bls. 13-33 og Sigríður Porgeirsdóttir, „Hvers vegna umhverfissiðfræði er róttæk grein hugvísinda. Um húmanisma og pósthúmanisma“, Náttúran i ljósaskiptunum, ritstjóri Björn Porsteinsson, Reykjavík: Heimspekistofnun - Háskólaútgáfan, 2016, bls. $55-74$.

28 Sjá til dæmis Wendy Wheeler, The Whole Creature. Complexity, Biosemiotics and the Evolution of Culture; Ólafur Páll Jónsson, „Maður og náttúra“, bls. 13-33; Sigríður 
vísindaheimspeki 20. aldar fólst til dæmis í tilraun til beinnar innleiðingar pröngrar raunvísindalegrar nálgunar í pau fræði. ${ }^{29}$

Hin vélræna smættunaraðferð vísinda og fræða einkennist af pví að til að nálgast skilning á gerð og starfsemi kerfa eða heilda eru pau hlutuð í sundur, í einingar sem eru metnar eða mældar með einhverjum hætti, og samhengi peirra síðan greint í formi orsaka og afleiðinga. Með pessu fást að sjálfsögðu margvíslegar gagnlegar upplýsingar um ákveðið samhengi hluta, og er alls ekki ætlunin að draga í efa mikla gagnsemi mikilvægra uppgötvana og pekkingarauka sem petta fræðastarf hefur leitt af sér. En vandinn sem pessari nálgun fylgir er kannski helstur sá hvernig sundurhlutun í einingarnar á sér stað, par sem mannhverf sýn á náttúruna ræður oftar en ekki ferðinni. ${ }^{30}$ Petta getur ráðið miklu um val orða og hugtaka sem notuð eru til að afmarka „einingarnar“ sem til verða við sundurhlutunina, og pegar vélarnálguninni er beitt á flókin kerfi náttúrunnar getur orðið til úr pví margbrotinn orsakavefur alls kyns eininga sem taldar eru mikilvægar í rannsókninni. Í sumum tilfellum geta einingarnar verið nánast tilfallandi hugarsmíð fræðimannsins, og vísað einungis á óljósan hátt til raunveruleika viðfangsefnisins. Hér reynir pví á skilning og gagnýna hugsun viðkomandi. Hinn pekkti próunarfræðingur Richard Lewontin skrifar að líffræðingar sem rannsaki líkama lífveru:

[...] líta alltaf á hana líffærafræðilegum augum, án pess að bjóða upp á skýran mælikvarða um hvernig eigi að ná slíku fram [...] Pannig brjóta peir lífveruna niður í hluta samkvæmt einhverju innsæi sem segir okkur meira um mannlega sálfræði og skynjun en raunveruleg tengsl milli líkamshluta dýra og plantna. ${ }^{31}$

Porgeirsdóttir, „Hvers vegna umhverfissiðfræði er róttæk grein hugvísinda“, bls. $55-74$.

29 Sjá til dæmis Samir Okasha, Philosophy of Science. A Very Short Introduction, Oxford: Oxford University Press, önnur útgáfa, 2016.

30 Sú hlið sem oft er gagnrýnd er að hin afmarkaða sýn á náttúruna sem vélhyggjan hvetur til, tengsl og samskipti eru skoðuð á forsendum (oft efnislegrar gerðar) hlutanna sem tengjast en tengslin sjálf, eðli peirra, fjölbreytni og ferlar, eru í öðru sæti. Pessi afmörkun getur orðið mjög bagaleg pegar kemur að lífverum, lífkerfum og -ferlum, og ég mun ræða pað betur síðar í greininni í tengslum við eðli vistkerfa og samband lífveru við umhverfi sitt.

$31, \ldots$ always anatomize it in some way, without offering a clear criterion for how this is to be done....In doing so they break the organism down into pieces by some intuative process that tells us more about the psychology of human perception than about the actual connections between parts of animals and plants." Richard Lewontin, The Triple Helix. Gene, Organism and Environment, bls. 77. 
Pegar svona er komið virðist sem öguð hugsun og hugtakasmíð vísindamanna, í anda grunnaðferðar heimspekinnar, eigi undir högg að sækja og er bá gjarnan vísað til hlutlægni peirra, andstætt huglægni sumra annarra fræða. Höfum í huga að hlutlægni á sér huglægar rætur, sem birtast meðal annars í pví hvernig hugtök sem nýtt eru eiga sér sögulegar, persónulegar og samfélagslegar forsendur, eru með öðrum orðum „staðsett pekking“ og koma ekki úr einhvers konar handanheimi meintrar hlutlægni. ${ }^{32}$ Heimspekingurinn Thomas Nagel fjallar meðal annars um petta í bók sinni The View from Nowbere en pessi titill segir í raun allt sem segja parf um hversu blind við oft erum á uppsprettur og forsendur peirra eininga sem við flokkum veruleikann $1 .{ }^{33}$ Einnig lítur út fyrir að hin prönga hlutlægnisnálgun sem hér er gerð að umræðuefni, geri beint og óbeint ráð fyrir að merking og gildi peirra hluta sem verið er að rannsaka felist með einhverjum dularfullum og oútskýrðum hætti í beim sjálfum og pá gjarnan einhvers konar efnislegum eiginleikum peirra. Pannig séu merking og gildi sjálfgefnar breytur í peirri abstrakt vélhyggjunálgun sem viðhöfð er, og parfnist ekki sérstaks - eða mun minna - tillits eða skoðunar. Eitt augljósasta dæmi nútímans um petta er sú orðræða að gen, sem eru efnisbútar kjarnsýrunnar DNA í kjörnum og hvatberum frumna, búi yfir sjálfstæðum eiginleikum eða virkni til að ákvarða proska og svipgerð lífvera, til dæmis útlit peirra, atferli, ákveðna hæfileika eða líkur sjúkdóma. Pannig er oft, til dæmis í fjölmiðlum, talað um „gen fyrir hinu og pessu“ og almennar kennslubækur í líffræði og virtar rannsóknastofnanir gera pað líka. Staðreyndin er sú að mikilvæg staða og starfsemi gena mótast alfarið af pví samhengi (e. context) og umhverfi, innan og utan frumunnar, sem pau starfa i. ${ }^{34}$

Vandinn sem ofangreind frásögn lýsir birtist meðal annars í pví að heimspeki og siðfræði eru nú orðið sjaldnast kenndar peim sem leggja stund á náttúruvísindi í háskólum nema pá í vel afmarkaðri vísindaheimspeki sem fæst við röklegar nálganir vísindalegrar aðferðafræði. Virtustu vísindamenn nútímans eins og Steven Hawking (1942-2018) halda bví jafnvel fram að heimspekin sé dauð, samanber pessi orð hans:

32 Donna Haraway, „Situated Knowledges. The Science Question in Feminism and the Privilege of Partial Perspective“, Feminist Studies, 1988, bls. 575-599.

33 Thomas Nagel, The View From Nowhere, Oxford: Oxford University Press, 1986.

34 Sonia Sultan lýsir pessu vandamáli vel, sjá Sonia E. Sultan, Organism \& Environment. Ecological Development, Niche Construction, and Adaptation, Oxford: Oxford University Press, 2015, bls. 1-2. 
Lífið er stutt og meðan pað varir könnum við aðeins brot af alheimi. En mennirnir eru forvitnar verur. Við undrumst og leitum svara. Í veröld sem skiptist á að vera mild og grimm hefur fólk spurt sig ótal spurninga, horfandi á óravíddir himingeimsins: Hvernig getum við skilið veröldina í kringum okkur? Hvernig hagar alheimurinn sér? Hvert er eðli raunveruleikans? Hvaðan kemur betta allt? Parfnaðist alheimurinn skapara? Flest okkar verja ekki miklum tíma í áhyggjur af bessum spurningum, en næstum allir velta peim stundum fyrir sér. Samkvæmt hefð heyra pessar spurningar undir heimspeki, en heimspekin er dauð. Hún hefur ekki haldið í við próun nútíma vísinda, einkum eðlisfræðinnar. Raunvísindamenn eru orðnir kyndilberar uppgötvana í pekkingarleit okkar. ${ }^{35}$

Yfirlýsingar Hawking fela vissulega í sér áhugaverðar frumspekilegar vangaveltur og spurningar, sem hafa beina tilvísun til allra fræða, lista og trúarbragða. ${ }^{36}$ John Dupré gerir sambærilega afneitun sumra líffræðinga á mikilvægi heimspeki í sínum fræðum að umræðuefni, og bendir á að á sama tíma og peir telja vísindi sín yfir heimspekina hafin, séu peir jafnframt á kafi í sínum eigin - gjarnan lítt öguðu - frumspekilegu útleggingum í nálgunum sínum. ${ }^{37}$ Einn vandinn er sá að pað form hlutlægrar nálgunar vísindanna sem hér er til umræðu tekur einungis að takmörkuðu leyti mið af siðferðilegum ígrundunum. ${ }^{38}$ Í ljósi pess að vönduð vísindaleg aðferð byggir umfram allt á gagnrýnni hugsun, sem er eitt af lykilviðfangsefnum heimspeki og siðfræði, ${ }^{39}$ pá er hér mikil og erfið mótsögn á ferðinni.

Afsiðun náttúrunnar í vísindum veldur pví að pau fara iðulega að snúast um afmarkaðar parfir mannsins, sem geta ráðist af sértækum hagsmunum

35 Stephen Hawking og Leonard Mlodinow, Skipulag albeimsins, Baldur Arnarsson og Einar H. Guðmundsson býddu, Reykjavík: Tifstjarnan, 2011, bls. 13. Undirstrikun er greinarhöfundar.

36 Sjá líka umfjöllun í Eyja Margrét Brynjarsdóttir, „Skynsemi eða rökleikni“, Frumgerðir og eftirmyndir. Aðferðir, eiginleikar og feminisk heimspeki, Reykjavík: Heimspekistofnun, 2019, bls. 112-113.

37 John Dupré, „The metaphysics of evolution“, Interface Focus 7/2017, bls. 1-9.

38 Sama rit; sjá einnig umfjöllun Ólafs Páls Jónssonar, „Maður og náttúra“, bls. 13-33.

39 Henry Alexander Henryson og Páll Skúlason, Hugleiðingar um gagnrýna bugsun, Reykjavík: Háskólaútgáfan, 2014. 
ákveðinna hópa eða fyrirtækja og/eða peirra sem fjármagna og/eða hagnýta niðurstöðurnar. Petta getur leitt til pess að ákvarðanir um hvað taka beri til rannsóknar, sem og framsetning og hagnýting vísindalegra uppgötvana, taki ekki - eða einungis að afmörkuðu leyti - tillit til siðferðilegra sjónarmiða, hvað pá heildrænnar sýnar á verðmæti náttúrunnar. Pannig hafa peir sem bera ábyrgð á og beita slíkum vísindum oft stuðlað að tæknilegum lausnum við nýtingu auðlinda náttúrunnar sem hafa, um leið og pau skapa sumum mikla auðlegð og velmegun, knésett vistkerfi jarðar og raskað lífi á jörðinni, ekki síst okkar eigin tilveru og menningu. Um petta eru mörg dæmi og fjölbreytt. Sum tengjast stríðsbrölti. Hinn frægi ádeilusöngvari Tom Lehrer kemur pessu vel til skila í lagi sínu um sprengjusérfræðing nasista og síðar Bandaríkjamanna, Werner von Braun, pegar hann leggur honum pessi orð í munn: „Ef eldflaugar fljúga skiptir engu hvar pær lenda, ekki mitt mál, segir Werner von Braun. “40 Hér afhjúpar háðið hina misskildu hlutlægni vísindamannsins, sem gjarnan er kallað „hlutleysi“. Vísindamaðurinn getur einbeitt sér að rannsóknum sínum, en látið „öðrum“ einstaklingum, stofnunum eða fyrirtækjum pjóðfélagsins eftir að ákvarða gagnsemi peirra og notkun.

Vandinn við framkvæmd og hagnýtingu vísinda og fræða tengist pví að við lifum í pjóðfélagi par sem kapítalísk markaðshugsun er ríkjandi, sem hvetur til samkeppni, endalauss hagvaxtar og aukinnar framleiðni. Pannig er fræðafólk hvatt til að framleiða pekkingu, sem leið til að hljóta viðurkenningu og jafnframt aðstöðu og fjármögnun til að stunda sín fræðistörf. Petta hefur meðal annars skilað sér í ofuráherslu á birtingu fræðigreina í tímaritum, bar sem veldisvöxtur hefur ríkt á undanförnum áratugum. ${ }^{41}$ Siðferðisvandinn sem tengist svona markaðshugsun hvetur fræðimanninn til að velja sér auðveld viðfangsefni sem hægt er að klára hratt og á sem einfaldastan hátt, og/eða að brjóta rannsókn sína niður í alls kyns smærri birtanlegar einingar sem falla að peim hugtakaheimi og aðferðum sem hann ræður við og pjónar jafnframt framleiðsluhugsuninni. Á sambærilegan og hnyttinn hátt ræðir Richard Lewontin um hvernig ríkjandi vélhyggja og smættunarhyggja hennar hefur leitt af sér ofureinfaldaða sýn á flókin kerfi og kynt undir hentistefnu vísindamanna pegar peir nálgast viðfangsefnið:

40 „Once rockets are up who cares where they come down that's not my department says Werner von Braun“, sjá eftirfarandi myndband: Tom Lehrer, „Werner von Braun“, Youtube, 11. júlí 2009, sótt 7. desember 2020 af https://www.youtube.com/ watch?v=TjDEsGZLbio.

41 Bjarni K. Kristjánsson og Skúli Skúlason, „Iðnvæðing háskóla. Hvernig markaðs- og nýfrjálshyggja mótar starfsemi háskóla á 21. öld“, Skírnir vor/2020, bls. 177-196. 
En árangur klukkulíkansins [...] hefur leitt til ofureinföldunar á sambandi hluta og heilda og orsaka og afleiðinga. Hluti af árangri einfeldningslegrar smættarhyggju og greininga er afleiðing hentistefnu vísindastarfs. Vísindamenn fást við pau vandamál sem henta aðferðum peirra, líkt og miðaldaher sem situr um borgir og nær að sigrast á vörnum peirra sem eru veikar, en skilur eftir svæði sem hafa náð að verjast. ${ }^{42}$

Рað parf ekki að tíunda fyrir lesandanum hvað petta getur býtt fyrir gæði og gagnsemi vísinda og fræða sem svona er komið fyrir. Brenglun gildismatsins vegna markaðs- og nýfrjálshyggju hefur reyndar sett pvílíkt mark á starf háskóla að fólk hefur risið upp til að spyrna við pessari próun. ${ }^{43}$ Vandinn er slíkur að hætta er á að vísindafólk hugsi lítið sem ekkert um siðferðilegar forsendur pess sem pað er að gera, heldur ani áfram í blindri trú á mátt vísindanna sem sjálfstæðs afls pekkingarleitarinnar.

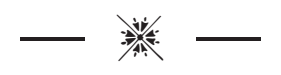

Prátt fyrir pá skuggalegu mynd sem hér er dregin upp, má minna á tvö mikilvæg og jákvæð atriði. Fyrra atriðið er að við sjáum greinilega viðleitni um allt samfélagið til að takast á við skaðlegar afleiðingar mannhverfrar drottnunargirni okkar í náttúrunni. Fræða- og vísindaheimurinn er engin undantekning. Pannig hefur hugmyndum og kenningum sem byggjast á heildrænni sýn á náttúruna, verið veitt sífellt meiri athygli, og hefur pað meðal annars birst í niðurrifi á múrum sérhæfingar fræðigreina og aukinni áherslu á pverfaglegar nálganir. Sem dæmi um petta er tilkoma umhverfissiðfræði og umhverfishugvísinda ${ }^{44}$ og aukinnar áherslu á heimspeki og sið-

42 „But the success of the clock model [...] has led to an overly simplified view of the relations of parts to wholes and causes to effects. Part of the success of naive reductionalisms and simplistic analysis comes from the opportunistic nature of scientific work. Scientists pursue precisely those problems that yield to their methods, like a medieval army that besieges cities for a period, subduing those whose defenses are weak, but leaving behind, still unconquered islands of resistance." Richard Lewontin, The Triple Helix. Gene, Organism and Environment, bls. 72-73.

43 Bjarni K. Kristjánsson og Skúli Skúlason. „Iðnvæðing háskóla. Hvernig markaðs- og nýfrjálshyggja mótar starfsemi háskóla á 21. öld“, bls. 177-196, og heimildir sem par er vitnað til.

44 Sjá til dæmis Sigríður Porgeirsdóttir, „Hvers vegna umhverfissiðfræði er róttæk grein hugvísinda“, bls. 55-74; og Guðbjörg R. Jóhannesdóttir og Porvarður Árnason, „Inngangur að pema“, bls. 1-8. 
fræði í kennslu og rannsóknum í umhverfismálum. ${ }^{45}$ Samhliða pessu hafa ýmsar kenningar, bæði gamlar og nýjar, ekki síst frá sjónarhóli náttúruvísinda og tengdrar heimspeki, sem beinast gegn einhliða vélhyggju og skoða heiminn meira sem heild kerfa og ferla, notið sífellt meiri athygli. ${ }^{46}$ Staðreyndin er sú að heimspekin, vísinda- og fræðaheimurinn allur hefur á að skipa fjölda fólks sem heldur fram hugmyndum og kenningum sem fela í sér mun meiri tengsla- og heildarhyggju en ríkjandi vélhyggja, en pessu fólki veitist erfitt að koma viðleitni sinni af hugmynda- og tilgátustiginu. Рað er ekki síst vegna - annars vegar - peirra takmarkana sem viðkomandi fræðigreinar hafa tamið sér pegar kemur að hugtakanotkun, orðræðu og aðferða við líkanasmíð og - hins vegar - vegna peirrar forgangsröðunar (par með talið skipulag fræðasamfélagsins og fjármögnunarmöguleika) sem fylgir ríkjandi tíðaranda og pví heljartaki sem vélhyggjan og hennar fylgifiskar hafa á samfélaginu og hugarheimi pess. En pað eru jákvæð merki um að við séum að brjótast út úr pessari menningu.

Seinna jákvæða atriðið er að máttur aðferðafræði vísinda og fræða er sannarlega mikill og hefur fært okkur pekkingu sem hefur umbylt samfélagi okkar og bætt lífið á margvíslegan hátt. Hér er vísað til beitingar gagnrýnnar hugsunar, samhliða kenningum og tilgátum sem hægt er að prófa. ${ }^{47} \mathrm{Um}$ er að ræða skipulega leit að bestu mögulegu pekkingu á hverjum tíma, sem veitir skilning og vinnur gegn bábiljum, röngum upplýsingum og falsfréttum sem ætíð fylgja okkur og hafa verið áberandi á undanförnum misserum. ${ }^{48}$

45 Hér má benda á ýmislegt, til dæmis ritgerðir í Náttúran í ljósaskiptunum.

46 Sjá til dæmis Brian G. Henning og Adam C. Scarfe, ritstjórar, Beyond Mechanisms; Denis M. Walsh, Organisms, Agency, and Evolution; Daniel J. Nicholson og John Dupré, ritstjórar, Everything Flows.

47 Hin vísindalega aðferð sem óx og dafnaði á tímum vísindabyltingarinnar, til dæmis í verkum manna eins og Galieleos (1564-1642), Kepplers (1571-1630) og Newtons (1643-1727) og svo síðar meðal líffræðinga eins og Darwins (1809-1882) og Wallace (1823-1913) sem settu fram próunarkenninguna á 19. öld, einkenndist af gagnrýnni skoðun upplýsinga sem aflað er með skipulagðri söfnun eða tilraunum með ákveðna tilgátu eða kenningu um fyrirbæri heimsins í huga. Pessari aðferð er að mínu mati best lýst sem öflugu hugsanakerfi sem stendur nokkuð sjálfstætt og hefur eins og dæmin sanna umbylt pekkingu okkar á heiminum og lifnaðarháttum. En pessi kraftmikla og sjálfstæða aðferðafræði varð til samhliða aukinni vélhyggju og áherslu á sérstöðu mannsins, og hefur verið stunduð í samfélögum sem einkennast af fylgifiskum pessa, ekki síst einstaklings- og smættunarhyggju og ofurtrúar á mátt tækni við hvers kyns úrlausnir verkefna og vandamála samtímans.

48 Hér bendi ég á Pjóðhátíðarpistil Finns Ulf Dellsén 17. júní 2020: „Gildi vísinda og gildin í vísindum“, par sem hann fjallaði um stöðu vísinda á tímum heimsfaraldursins COVID-19, og benti á hvaða lærdóm má draga af faraldrinum. Pistillinn er 
Hvað árangurinn snertir nægir að nefna sem dæmi framfarir í læknisfræði, landbúnaði, sjávarútvegi, hvers kyns tæknihönnun, skipulags- og stjórnunarfræðum sem hafa haft margvísleg mikilvæg og jákvæð áhrif. Pessi pekking er aftur á móti gjarnan afmörkuð við pætti sem varða framgang og velgengni mannsins, á kostnað heildstæðrar pekkingar á umhverfi okkar og annarra lífvera - og gangi mála í náttúrunni almennt.

Meirihluti fólks treystir vísinda- og fræðastarfi, sem endurspeglast í jákvæðri afstöðu pess til háskóla. ${ }^{49}$ Sem aðsetur vísinda og fræða hafa háskólar verið lykilstofnanir í próun samfélaga og pjóða. Mikilvægi fræðilegrar og tæknilegrar pekkingar í baráttunni við yfirstandandi heimsfaraldur og pann menningarvanda sem fylgir honum, sem og færar leiðir til að takast á við loftslagsröskun og hrun líffræðilegrar fjölbreytni, er langflestum augljós. Раð má pví segja að ábyrgð allra sem stunda vísinda- og fræðistörf sé mikil, og brýnt er að skynsemi, víðsýni og traust siðferði sé eflt og viðhaldið. Pessi starfsemi verður að standa undir peim væntingum sem til hennar eru gerðar.

\section{Maðurinn sem órofa bluti af náttúrunni}

Sú rödd heyrist æ oftar að maðurinn sé hluti náttúrunnar og við purfum að haga lífi okkar í auknum mæli í samræmi við pað. Lögð er áhersla á siðferðislega hlið vandans, og bent á að leiðin að breyttri hegðun sé að átta sig betur á verðmætum náttúrunnar í víðum skilningi og rækta siðferðið á forsendum peirra. En hvernig förum við að pví?

Til að svara pessari spurningu er hjálplegt að hugsa um lífið sjálft. Рað felur í sér skapandi framvindu par sem samhengi hlutanna gefur lífinu, í víðri merkingu, möguleika og tækifæri til að dafna. Hinn skapandi eiginleiki lífsins tengist peim sértæka eiginleika lífvera og lífkerfa að vera sjálfskapandi (e. autopoetic)..$^{50}$ Sköpun í framvindu lífsins kallar á orð eins og undrun, reynslu, merkingarbærni og notagildi par sem afurðin fyrir mann-

aðgengilegur á netinu, sóttur 7. desember af: https://www.ruv.is/utvarp/spila/thjodhatidarpistill-gildi-visinda-og-gildin-i-visindum/30555/93cklh.

49 Sjá til dæmis „Traust til heilbrigðiskerfisins, lögreglunnar og dómskerfisins lækkar“, Gallup, 26. febrúar 2020, sótt 7. desember 2020 af https://www.gallup.is/frettir/ traust-til-heilbrigdiskerfsins-logreglunnar-og-domskerfisins-laekkar/.

50 Sjá til dæmis umfjöllun hjá Evan Thompson, Mind in Life. Biology, Phenomenology, and the Science of Mind, Cambridge Massachusetts: Harvard University Press, 2007, bls. 92 og Adam C. Scarfe, „On a „Life-Blind Spot in Neo-Darwinism’s Mechanistic Methaphysical Lens"“, Beoyned Mechanism - putting life back into biology, ritstjórar Brian G. Hennig og Adam C. Scarfe, Plymouth: Lexington Books, 2013, bls. 25-64, hér bls. 27-28. 
inn er meðal annars menningin, en fyrir lífheiminn í heild: starfhæf lífog vistkerfi sem menningin er að sjálfsögðu hluti af. Pessi nálgun lítur í raun á lífið sem sögulega framvindu, par sem brugðist er við aðstæðum og möguleikum sem gefast. Tilvist og proski hverrar lífveru er pví hugsaður sem samfelldur ferill (e. process) og próun stofna lífvera sömuleiðis. Til samanburðar pá býður einhliða áhersla á vélarsamlíkingu upp á statískari og tímalausari sýn par sem saga hlutanna skiptir minna máli. ${ }^{51}$

Vélræn sýn, sem einbeitir sér alfarið að orsökum og afleiðingum í samverkun kerfiseininga, getur átt erfitt með að höndla skapandi eiginleika lífsins og/eða peir fá pví mun minni athygli. Heildarmyndin er augljóslega eitthvað meira en samverkun peirra eininga sem vélarsamlíkingin kýs að skoða hverju sinni. Heimspekingurinn Adam C. Scarfe, sem er annar af ritstjórum bókarinnar Beoyned Mechanism - putting life back into biology, ræðir pennan vanda vélhyggjusýnarinnar sem líf-blinda blettinn, (e. life-blind spot $)^{52}$, sem undirstrikar að heimsmynd vélhyggjunnar gefur lítið svigrúm (allavega mjög mannhverft) fyrir pá skapandi framvindu sem við sjáum í náttúrulegum ferlum og pá hvað helst í lífinu sjálfu. Í sumum tilfellum getur líf-blindi blettur vélrænnar sýnar verið önnur birtingarmynd pess siðferðilega vanda sem áður er ræddur. Par með er talin afsiðun náttúrunnar sem hefur leitt okkur að hengiflugi pess umhverfisvanda sem nú er ef til vill flestum ljós.

Bent hefur verið á að sú heimsmynd par sem veröldin er hugsuð sem samfelldur ferill (e. process), veiti mun meira rými fyrir hinn sífellt skapandi veruleika lífsins, tilurð merkingar og gilda, og pá ekki síst að slík sýn geri sjálfkrafa ráð fyrir manninum sem hluta náttúrunnar par sem leiðin til að lifa, vera til og afla pekkingar og skilnings á öllu í kringum sig, er byggð á

51 Pannig skilgreinir Armin Moczek hugtakið proski (e. development) í anda ferlahugsunar: „the sum of all processes and interacting components that are required to allow organismal form and function, on all levels of biological organization, to come into being“, Armin Moczek, „Towards a theory of development through a theory of developmental evolution", Towards a theory of development, ritstjórar Alessandro Minelli og Thomas Pradue, Oxford: Oxford University Press, 2014, bls. 218-226, hér bls. 218. Og varðandi líffræðilega próun á sambærileg ferlahugsun við: „Evolution is not an unfolding but an historically contingent wandering pathway through the space of possibilities“, sjá Richard Lewontin, The Triple Helix. Gene, Organism and Environment, bls. 88. Hafa verður í huga að í vísindum eru vélar- og ferlanálganir ekki endilega einhliða andstæður, heldur má beita peim saman til að öðlast pann skilning sem sóst er eftir.

52 Adam C. Scarfe, „On a „Life-Blind Spot in Neo-Darwinism's Mechanistic Methaphysical Lens““, til dæmis bls. 38-42. 
stanslausri reynslu. ${ }^{53}$ Reynslupekking af pessum toga vísar ekki síst til pess að fræðafólk stundi sitt starf með virðingu fyrir viðfangsefninu að leiðarljósi og upplifi sig á öllum stigum rannsóknarinnar sem hluta af peirri náttúru sem pað er að læra um..$^{54}$ Gott dæmi um slíkan fræðimann er Barbara McClintock, einn helsti erfðafræðingur 20. aldarinnar, og ekki er tilviljun að ævisaga hennar ber heitið A Feeling for the Organism. ${ }^{55}$ Heimspekingurinn Alfred North Whitehead (1861-1947) horfði til sköpunareiginleika lífkerfa pegar hann setti fram kenningar sínar um ferlahugsun (e. process thinking), og Adam C. Scarfe dregur fram styrkleika peirrar nálgunar í ofangreindum bókarkafla, par sem lífið er ekki lengur blindur blettur, heldur fá sköpun og gildi sinn sess í heimssýninni. ${ }^{56}$ Roope O. Karoneen útfærir pennan siðferðilega styrk ferlahugsunarinnar vel pegar kemur að umhverfismálum, og bendir meðal annars á hvernig hún getur eflt nálgun, skilning og viðbrögð okkar við framvindu loftslagsbreytinga. ${ }^{57}$

Einn stærsti vandinn við innleiðingu heildrænnar heimsmyndar er að orðræða okkar og hugtakanotkun er svo mótuð af hinni vélrænu og mannhverfu heimsmynd að við eigum erfitt með að hugsa og tjá okkur um pá breyttu sýn sem hér er gerð krafa um: að við lítum á okkur sem órofa hluta náttúrunnar og virka pátttakendur í öllum peim kerfum og ferlum sem par eru að verki. Til dæmis hefur reynst erfitt að innleiða hugtök ferlahugsunarinnar pannig að pau gagnist, svo sem í lífvísindum par sem vélræn - og oft mjög statísk - mynd af proska lífvera, vistkerfum og líffræðilegri fjölbreytni, er enn mjög ráđandi. Petta má sjá í kennslu í skólum og stefnumótun í náttúruvernd. ${ }^{58}$

53 Pessi hugsun er mjög skýr hjá Wendy Wheeler, The Whole Creature, til dæmis bls. 47-49; og sömuleiðis hjá Guðbjörgu R. Jóhannesdóttur, „Vá! - Undrun, fegurð og ægifegurð í upplifun af íslenskri náttúru“, Náttúran í ljósaskiptunum, ritstjóri Björn Porsteinsson, Reykjavík: Heimspekistofnun - Háskólaútgáfan, 2016, bls.143-168.

54 Skúli Skúlason, „Að hafa tilfinningu fyrir náttúrunni í vísindum“, Tímarit Máls og menningar 2/2014, bls. 11-19.

55 Evelyn Fox Keller, A Feeling for the Organism. The Life and Work of Barbara McClintock, San Francisco: W. H. Freeman and Co., 1983.

56 Adam C. Scarfe, „On a „Life-Blind Spot in Neo-Darwinism's Mechanistic Methaphysical Lens"“", Beoyned Mechanism - putting life back into biology, bls. 25-64.

57 Roope O. Karoneen, „Reframing tacit human-nature relations. An inquiry into process philosophy and the philosophy of Michael Polanyi“, Environmental Values 2/2018, bls. 179-201.

58 Sjá til dæmis: Thomas B. Smith, M.W. Bruford, og R.K. Wayne, „The Preservation of Process. The Missing Element of Conservation Programs“, Biodiversity Letters $1 / 61993$, bls. 164-167. 
Verkefni okkar er pví að takast með skipulegum hætti á við spurningar eins og: Hvernig getum við upplifað okkur og umgengist annað fólk og náttúruna í heild með ofangreinda heildarsýn og áherslu á ferla náttúrunnar að leiðarljósi? Hvernig getum við beitt peirri nálgun til að víkka og proska hugsun okkar, hugtaka- og orðanotkun, sköpunargáfu, siðferðisvitund og lifnaðarhætti? Hér kemur vissulega margt upp í hugann en til að nálgast petta verkefni af peirri dýpt og alvöru sem pað krefst, pá er nauðsynlegt að skoða vandlega hver sé hin eiginlega uppspretta gilda, par með talið siðferðilegra. Í slíkri athugun verður að beita saman heimspekilegri greiningu og peirri pekkingu sem vísindin - og pá sérstaklega lífvísindin búa yfir. Hér er um flókið samspil að ræða. Samhliða og/eða í kjölfar slíkrar greiningar er án efa nauðsynlegt að endurskoða orða- og hugtakanotkun okkar og leita í smiðju heimspekinga, annarra fræðimanna og listamanna í pessu víðtæka og fjölpætta verkefni.

\section{Vistkerfi, liffreðileg fjölbreytni og tengsl lifvera við umbverfi sitt}

Hefjum pessa umræðu á pví að skoða grunnhugtak vistfræðinnar, vistkerfi (e. ecosystem). Hugtakið vísar til pess hvernig einstaklingar, afbrigði, stofnar, tegundir og samfélög lífvera eru innbyrðis tengd, sem og hvernig sambandi lífveranna við pann hluta umhverfis peirra sem er ekki lifandi er háttað, svo sem berggrunn og landslag, sem og eðlislæga eiginleika láðs og lagar. Lykilorðið hér er „kerfi“, sem vísar til pess margvíslega samhengis sem vistkerfi felur í sér og er forsenda pess að pað geti starfað og veitt lífverunum sem par er að finna tilverugrundvöll. Pessi tilverugrunnur lýsir sér meðal annars í pví að vistkerfi veitir lífverum pá orku og næringu (oft skilgreint sem fæðukeðja) sem pær purfa til að lifa af, sem og ólífrænar aðstæður eins og súrefni til að geta andað, nauðsynleg steinefni, vatn, og síðast en ekki síst búsvæði til að afhafna sig og lifa lífinu. Pessir pættir, sem fela í sér lífsins nauðsynjar, eru stundum útskýrðir sem vistkerfispjónusta, sem reyndar er beint alfarið að pörfum mannsins, en mætti útfæra sem víðari verðmæti og gildi kerfanna. ${ }^{59}$ Líffræðingar beita vistkerfishugtakinu á

9 Sjá til dæmis Alessandra La Notte, Dalia D’Amato, Hanna Mäkinen, Maria Luisa Paracchini, Camino Liquetea, Benis Egoh, Davide Geneletti, Neville D. Crossman, „Ecosystem services classification. A systems ecology perspective of the cascade framework“, Ecological Indicators 74/2017, bls. 392-402. Hefðbundin skilgreining hugtaksins vistkerfapjónusta (e. ecosystem service), er reyndar algjörlega sniðin að 
ýmsan hátt og er skalinn mjög breiður, allt frá pví að skoða vistkerfi örvera í pörmum dýra, vistkerfi mólendis, stöðuvatna, hafsvæða eða allrar jarðar.

Á sama tíma og líffræðin kennir okkur að allar lífverur, að manninum meðtöldum, séu byggðar með sömu lífrænu efnum, til dæmis kjarnsýrum erfðaefnisins (DNA og RNA) og próteinum (sem eru meginefni í frumum og vefjum lífvera), er jafnframt ljóst að lífverur eru mjög fjölbreyttar í útliti, atferli og lífssögu, og pessi fjöbreytni endurspeglast enn fremur í peim sífelldu breytingum sem einkenna próun lífverustofna og tegunda. Fjölbreytnin er mjög vel greinanleg, frá smæstu veirum og einfrumungum (örverum) til stærstu spendýra eins og steypireyðar. Lífverur má frekar flokka í röklegt kerfi, sem endurspeglar tilkomu peirra, sögu og próun - oft vísað til sem lífstrésins (e. tree of life). Allur pessi fjölbreytileiki í tíma og rúmi, hvernig hann verður til og starfar og hvernig honum vindur fram í tímans rás, er ein af stóru spurningum líffræðilegrar próunarfræði og náttúra Íslands er einstaklega áhugaverð til rannsókna á pessu sviði. ${ }^{60}$ Pannig er fjölbreytnin nátengd stöðu lífveranna í vistkerfinu, sem er best lýst með peim hætti að pær eru aðlagaðar umhverfi sínu; breytileikinn er í beinu sambandi við pá pætti vistkerfisins sem gera lífverunni kleift að lifa og dafna. Samband og samskipti lífveranna sín á milli eru dæmi um petta. Í stuttu máli má segja að útlit, atferli og lífssaga lífvera endurspegli pað umhverfi sem pær hrærast í. Vistkerfi og tengslaheimur peirra fela pannig í sér meginatriði pess sem í daglegu tali er nefnt liffræðileg fjölbreytni, ${ }^{61}$ og er ein meginskýring pess hvers vegna hugtakið er svo mikilvægt og lagt til grundvallar við stefnumótun um nýtingu og náttúruvernd, bæði á lands- og heimsvísu. Á sama tíma og vistkerfi grundvallast á líffræðilegri fjölbreytni, er tilkoma og eðli fjölbreytninnar byggð á tilvist, starfsemi og pjónustu vistkerfisins.

Maðurinn er að sjálfsögu hluti af öllu pessu og eins og aðrar lífverur algjörlega háður vistkerfinu sem hann tilheyrir. Líffræðingar líta nú í æ ríkari mæli á fjölfruma lífverur sem samsett lífkerfi. Pannig sé rétt að skoða

hagsmunum mannsins, sem endurspeglar pann hugarheim sem vistfræðin hrærist í; aftur á móti má vel nota hugtakið til að sjá fyrir sér heildræna „pjónustu“ sem gerir lífkerfum kleift að starfa og viðhalda sér.

60 Sjá yfirlitsgreinina: Skúli Skúlason og Sigurður S. Snorrason, „Fjölbreytni og próun bleikjunnar í Pingvallavatni“, Náttúrufreðingurinn 1/2020, bls. 126-138.

${ }^{61}$ Eftirfarandi er skilgreining Sameinuðu pjóðanna sem oft er notuð: „Líffræðileg fjölbreytni merkir breytileika meðal lífvera í margbreytilegu umhverfi, par með eru talin vistkerfi á landi, sjó og vötnum, og pau vistfræðilegu kerfi sem pær eru hluti af; petta nær til fjölbreytni innan tegunda, milli tegunda og meðal vistkerfa“, CBD, Convention on Biological Diversity. Rio Eatch Summit, 5. júní 1992. 
proska fjölfrumunga - eins og okkur mannanna - frá okfrumu til fullorðinnar lífveru, sem proskakerfi sem vindur fram í beinu og óbeinu samhengi við pað vistkerfi sem lífveran er hluti af. Til að styðja pessa afstöðu enn frekar er nú vel pekkt að líkamar fjölfrumunga innihalda ógrynni örvera, svo sem baktería, sem eru starfsemi líkamans lífsnauðsynlegar, pótt okkur sé tamara að hugsa um slíkar lífverur sem hættulegar og óæskilegar meðal annars vegna sjúkdóma sem af sumum peirra hljótast. ${ }^{62}$ Pessi nálgun gerir tilvist lífverunnar sem sjálfstæðrar meðvitaðrar einingar óljósa og hvetur mun frekar til pess að sjá lífverur sem heildstæðar samvinnueiningar, pað er vistkerfi. Меð öðrum orðum er hugtakið „einstaklingur“, eins og við hugsum almennt um pað, í raun afar flókið samsett fyrirbæri sem saman myndar proskaferil lífverunnar og er hluti af pátttöku hennar í vistkerfinu. Og til að öðlast skilning á proska, próun og fjölbreytni verður að nálgast „einstaklinginn“ með pessum hætti. ${ }^{63}$

Eins og ofangreind lýsing felur í sér eru innbyrðis háð tengsl eitt af megineinkennum lífkerfa og vistkerfa jafnt sem proskakerfa lífvera; gagnsemi tengslanna getur verið mjög mikil og oft lífsnauðsynleg. Мeð öðrum orðum: í starfsemi, ferlum og birtingarmyndum pessara náttúrulegu kerfa, par með talið í fjölbreyttu útliti lífvera, má leita að uppsprettu alls pessa síkvika og skapandi tengslaheims, sem gera tilvist og framvindu lífsins mögulega og sérstæða. Petta er nákvæmlega bað sem einhliða vélræn nálgun á líf- og vistkerfi getur átt erfitt með að höndla. Í ofuráherslu á sundurhlutun eininganna og einfaldri skoðun á samvirkni peirra pvælist blindi-blettur lífsins fyrir, og prátt fyrir mikla viðleitni líffræðinga - oft með góðum árangri $^{64}$ - til að brjótast undan hinu hulda valdi vélhyggjunnar er enn mikið verk óunnið.

Á fyrri hluta og fram yfir miðja 20. öld bar talsvert á hugmyndum og kenningum í líffræði sem beindust gegn einhliða vélhyggju. Pá fæddist meðal annars ákveðin kerfishugsun sem lagði grunninn að svokallaðri kerfislíffræði (e. systems biology) par sem tekist er á við flókin og ólínuleg sambönd lífkerfa, með skapandi mátt kerfanna, samhliða kenningum með

62 Petta er vel kynnt í bók Scott F. Gilbert og David Epel, Ecological Developmental Biology. The Environmental Regulation of Development, Massachusetts: Sineuer Associates Inc., 2015, bls. 79-128.

63 Sjá Scott F. Gilbert, J. Sapp og A. I. Tauber, „A symbiotic view of life. We have never been individuals“, The Quarterly review of biology 87/2012, bls. 325-341.

${ }^{64}$ Framlag líffræðinganna, Armin Moczek, Scott F. Gilbert, Sonia Sultan og Richard Lewontin, sem áður hefur verið vitnað til, er gott dæmi um pað. 
ferlahugsun, að leiðarljósi. ${ }^{65}$ Pessi viðleitni náði ekki fótfestu í ráðandi hugarheimi vélhyggjunnar, sem allt fram á pennan dag einkennir öll pessi fræði. Prátt fyrir pað hafa margvíslegar hugmyndir og kenningar sem beinast að skapandi samvirkni kerfa og ferla náð að festa sig í sessi og náð ákveðnu flugi á undanförnum árum, meðal annars í proskunar- og próunarfræði og í tengslum við umhverfismál og kenningar um stöðu mannsins í náttúrunni. ${ }^{66}$

\section{Tengsl lifveru og umbverfis og uppspretta merkingar}

Hugtakið „vist“ (e. niche) er miðlægt í vistfræði og er oft notað nokkuð frjálslega, en vísar til pess hvaða páttum lífveran - stofn lífvera eða tegundin - er tengd lifandi og lífvana umhverfi sínu. Pessir pættir geta verið aðrar lífverur, búsvæði, fæða, jafnt sem eðlislægir pættir eins og hiti, raki og selta. Umhverfið getur verið bæði innan og utan viðkomandi lífvera. Parna er áherslan á parfir lífverunnar, í formi tengsla sem skilgreina tilvist hennar á hverjum tíma og eru forsendur pess að hún geti lifað í viðkomandi vistkerfi. Рað kemur pví ekki á óvart að pegar leitast er við að skýra próunarlega aðlögun lífvera, til dæmis hvað snertir líkamslögun, vöxt eða atferli, benda líffræðingar á að pað sé fyrst og fremst samband lífverunnar við umhverfi sitt sem skiptir máli, pað sé til dæmis grundvöllur pess vals náttúrunnar sem á sér stað í frampróun kynslóðanna og var pungamiðjan 1 próunarkenningu Darwins. ${ }^{67}$ Grunnhugmyndin um náttúrulegt val felst einmitt í pví hvernig pau gæði sem felast í pessu sambandi varða afkomu lífveranna í peim stofni sem rannsóknin beinist að, hvað margir nái að lifa og dafna og hvað margir afkomendur komast á legg. ${ }^{68}$ Fjölbreytnin í

65 Sjá gott yfirlit í John Dupré og Daniel J. Nicholson, „A Manifesto for a Processual Philosophy of Biology, bls. 7-11.

66 Sem dæmi má benda á: Susan Oyama, The Ontogeny of Information. Developmental Systems and Evolution, Duke University Press, 2. útgáfa, 2000; Richard Lewontin, The Triple Helix. Gene, Organism and Environment, bls. 77; Wendy Wheeler, The Whole Creature, 2006; Scott F. Gilbert og David Epel, Ecological Developmental Biology. The Environmental Regulation of Development, Massachusetts: Sineuer Associates Inc., 2015; Guðbjörg R. Jóhannesdóttir, „Vá! - Undrun, fegurð og ægifegurð í upplifun af íslenskri náttúru“, bls. 143-168; Daniel J. Nicholson og John Dupré, ritstjórar, Everything Flows.

67 Petta er vel útskýrt hjá Sonia E. Sultan, Organism \& Environment. Ecological Development, Niche Construction, and Adaptation, Oxford: Oxford University Press, 2015.

68 Sjá nánari skýringar í Skúli Skúlason og Sigurður S. Snorrason, „Fjölbreytni og próun bleikjunnar í Pingvallavatni“, bls. 126-138. 
pessum tengslum og birtingarmyndum peirra er lykilatriði, án breytileika (valkosta) verður ekkert val, engin próun. Nýlegar rannsóknir próunarfræðinga á tengslum lífvera við umhverfi sitt hafa í síauknum mæli beinst að pví hvernig lífverur móta umhverfið, oftar en ekki sjálfum sér og öðrum (jafnvel öðrum tegundum) til hagsbóta. Petta hefur leitt af sér hugtakið „vistmótun“ (e. niche construction). ${ }^{69}$ Vistmótun nær auðvitað til mannsins; hún er forsenda lífs okkar og samfélaga, en hér höfum við pó helst beint sjónum að neikvæðum hliðum hennar. Umhverfið mótar einnig proskaferil einstakra lífvera (innan kynslóða), sem getur aukið aðlögunarhæfi viðkomandi einstaklinga og hefur áhrif á fjölbreytni stofnsins. ${ }^{70}$

Hér er vissulega um áhugaverða og mikilvæga próun fræðanna að ræða, par sem samspil tengsla og ferla er skoðað. Til að geta lýst pessu öllu nota líffræðingar urmul af hugtökum og orðum, sem oft fela í sér að skilaboð og samskipti í formi tákna eigi sér stað, til dæmis pegar peir lýsa samskiptum milli frumna í líkamanum. En vandinn er sá að nálgunin takmarkast að miklu leyti við athugun á orsökum og afleiðingum í beinum tengslum peirra atriða og hluta sem sambandið varðar. Til dæmis er lífveran sögð hafa áhrif á eitthvað í umhverfi sínu (til dæmis aðra lífveru), sem orsakar viðbrögð af einhverju tagi, sem svo geta haft áhrif til baka á lífveruna. Pannig geti myndast markviss tengslaferill í formi gagnkvæmra viðbragða (e. reciprocal causation). Hér læðist að hugarheimur og orðræða vélhyggjunnar, sem reynir að skýra sambandsvefinn, og pá ferla sem honum tengjast, fyrst og fremst á forsendum „eininganna“ sem eru í samvirkninni, en ekki á tengslaferlinum sjálfum - einkennum hans og peim upplýsingum sem hann býr yfir. Vandinn magnast svo auðvitað pegar umræddar „einingar“ sem eru í samvirkni eru byggðar á mannhverfum hugtökum og endurspegla reynsluheim, eða augnabliks ákvörðun viðkomandi vísindamanns frekar en lífverunnar og umhverfisins sem hann er að rannsaka og reyna að skýra. ${ }^{71}$

69 Sjá til dæmis Kevin Laland, Blake Matthews og Marcus W. Feldman, „An introduction to niche construction theory“, Evolutionary Ecology 30/2016, bls. 191-202.

70 Sjá til dæmis David W. Pfennig, M. A. Wund, E. C. Snell-Rood, T. Cruickshank, C. D. Schlichting og A. P. Moczek, „Phenotypic plasticity's impacts on diversification and speciation“, Trends in Ecology \& Evolution 25/2010, bls. 459-467; Skúli Skúlason, K. J. Parsons, R. Svanbäck, K. Räsänen, M. M. Ferguson, C. E. Adams, P-A. Amundsen, P. Bartels, C. W. Bean, J. Boughman, G. Englund, J. Guðbrandsson, O. E. Hooker, A. G. Hudson, K. K. Kahilainen, R. Knudsen, B. K. Kristjánsson, C.A.-L. Leblanc, Z Jónsson, G. Öhlund, C. Smith og S. S. Snorrason, „A way forward with eco evo devo. An extended theory of resource polymorphism with postglacial fishes as model systems“, Biological Reviews 94/2019, bls. 1786-1808.

71 Sjá fyrri umfjöllun, og Richard Lewontin, The Triple Helix. Gene, Organism and 
Lífefnafræðingurinn og heimspekingurinn Jesper Hoffmeyer (19422019) bendir á að vandinn liggi í pví að hugtakið túlkun (e. interpretation) sé ekki tekið nógu alvarlega, og í mörgum tilfellum, sniðgengið í pessum greiningum. Меð öðrum orðum, eins og fram kom að framan, senda lífverur og lífefni frá sér og taka á móti urmul skilaboða frá umhverfi sínu í formi tákna (e. signal eða sign), sem eru með einhverjum hætti numin og túlkuð og birtingarmynd túlkunarinnar er ákveðin merking eða skilningur. ${ }^{72}$ Táknið getur pannig verið fullkomlega merkingarlaust í sjálfu sér, en раð sem pað gefur til kynna fær merkingu vegna sambandsins sem um ræðir, og sú merking hefur oft talsvert notagildi. Táknið birtist pannig í tengslum lífverunnar eða lífkerfa við umhverfi sitt og getur hjálpað til við að skilja eðli pess sambands. Fjöldamörg misflókin dæmi má nefna hér, til dæmis tengsl bráðar og rándýrs. Í stað pess að flýja stoppar hérinn og stillir sér upp pegar hann sér ref á veiðum í talsverðri fjarlægð. Refurinn sér pessi viðbrögð hérans og getur í kjölfarið túlkað skilaboðin - gefið peim merkingu - pannig að ekki borgi sig að reyna að halda pessu áfram, hérinn hafi séð hann og muni augljóslega ná að forða sér. Skilaboðin sem „stoppa og stilla sér upp“ fela í sér eru augljóslega túlkuð, og niðurstaðan hentar í pessu tilfelli báðum aðilum. Gjörólíkt, en röklega sambærilegt dæmi, sem tengist mótanleika umhverfisins, er eftirfarandi. Vatnaflær eru lítil krabbadýr sem eru algeng í tjörnum og stöðuvötnum, og eru vinsæl fæða fiska. Rannsóknir hafa sýnt að í proskaferli vatnaflóa geta pær greint efni sem fiskarnir gefa frá sér, og í kjölfarið mynda pær oddhvassa hjálma á höfðinu sem gerir fiskum erfiðara um vik að éta pær. Tilraunir leiddu í ljós að efnin höfðu pessi áhrif óháð pví hvort fiskur væri í tilraunabúrinu. Táknin sem efnin fela í sér eru pannig túlkuð og sú merking sköpuð að hætta sé á ferðum í formi ránfisks og oddhvass hjálmur proskast í kjölfarið. ${ }^{73}$ Enn annað dæmi (að pessu sinni stílfært dæmi úr proskunarfræði) er pegar ákveðið prótein sem binst frumuhimnu sendir með pví skilaboð til ákveðins gens í kjarna frumunnar, sem er túlkað og hefur áhrif á starfsemi gensins í proskaferli svipgerðarinnar, til dæmis myndun kjálkabeina sem

Environment, bls. 77.

72 Jesper Hoffmeyer, Biosemiotics. An Examination into the Signs of Life and the Life of Signs, Chicago: University of Scranton Press, 2008; sjá líka, Towards a Semiotic Biology. Life is the Action of Signs, ritstjórar Claus Emmeche og Kalevi Kull, London: Imperial College Press, 2011.

73 David W. Pfennig, M. A. Wund, E. C. Snell-Rood, T. Cruickshank, C. D. Schlichting og A. P. Moczek, „Phenotypic plasticity's impacts on diversification and speciation“, Trends in Ecology \& Evolution 25/2010, bls. 459-467. 
eru mikilvæg lífverunni til fæðuöflunar. Pað sem meira er, túlkun sambærilegra tákna (skilaboða), til dæmis sama próteinsins, getur verið mismunandi milli einstaklinga og sömuleiðis proskastiga sama einstaklings, allt eftir pví hvernig aðstæður eru hverju sinni, svo sem mismunandi proskastig lífverunnar í pessu dæmi. ${ }^{74}$ Táknin geta pannig leitt til margvíslegrar merkingar, allt eftir stöðu pess og pörfum sem túlkar pau. Pessi ólíku dæmi sýna fjölbreytnina sem hér er um að ræða, og gefur vísbendingu um hversu flókinn vefur gagnkvæmra tákna, túlkunar og merkingar getur verið.

Pennan fræðaheim má nefna líftáknfræði, sem er býðing á enska orðinu biosemiotics, en hann er nátengdur peirri táknfræði sem við eigum að venjast, og snýst fyrst og fremst um tungumálið. Tungumál okkar og annarra dýra er byggt á táknum sem vísa til ákveðinna eininga, hluta og atburða og ferla í umhverfinu og gera okkur kleift að lifa og starfa, eiga samskipti og hugsa. Táknin sjálf eru auðvitað merkingarlaus sem slík, en pau hjálpa við að gefa hlutum merkingu, og oft skiptir sú merking miklu máli í ferli lífsins, eðli skilnings, ákvarðanatöku og framkvæmdum - getur sem sagt verið birtingarmynd gilda sem fæðast vegna peirra tengsla sem myndast. Sem sambærilegt dæmi getum við séð fyrir okkur beittan hníf. Við ákveðnar aðstæður gefum við hnífnum merkingu eldhúshnífs, pví hann gagnast til dæmis til að skera hvítkál, en við aðrar aðstæður fær hann merkinguna vopn, til dæmis pegar við purfum að verja líf okkar. Hér er augljóslega um túlkanir og ákvarðanir að ræða sem hafa sterka siðferðislega tilvísun; hnífinn má sannarlega nota bæði til góðs og ills. Sambærilegar „ákvarðanir" byggðar á aðstæðum og skilaboðum einkenna starfsemi allra líf- og vistkerfa og má að vissu marki nálgast með sambærilegri rökskipan táknfræðinnar. ${ }^{75}$ Höfum í huga að stór hluti ákvarðana í daglegri líkamlegri starfsemi okkar er af pessum meiði, pó hann sé okkur ekki beinlínis meðvitaður, til dæmis líkamleg viðbrögð sem koma í veg fyrir að við förum okkur að voða í hættum daglegs lífs.

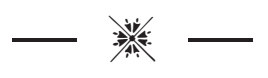

74 Scott F. Gilbert, „Ecological Developmental Biology. Interpreting Developmental Signs“, Biosemiotics 9/2016, bls. 51-60.

75 Líftáknfræðin byggir mikið á táknfræðum og heimspeki Charles Sanders Peirce (1839-1914), sjá Jesper Hoffmeyer, Biosemiotics. An Examination into the Signs of Life and the Life of Signs, til dæmis bls. XV. 
Fræðilegur grunnur líftáknfræðinnar á sér ekki síst rætur í kenningum líffræðingsins og heimspekingsins Jakobs von Uexkülls (1864-1944) um tengsl lífvera við umhverfi sitt. Grunnur peirra felst í að skilgreina hugtakið „umhverfi“ sem pann hluta veruleikans (náttúrunnar) sem lífveran er í víðum skilningi tengd hverju sinni. ${ }^{76}$ Umhverfishugtakið er pannig algjörlega byggt á pessum tengslaheimi, sem von Uexküll nefndi Umwelt, og eðlilegast er að pýða á íslensku sem umheim. ${ }^{77}$ Páll Skúlason heimspekingur notar svipaða nálgun á umhverfi mannsins í bókinni Umbverfing. ${ }^{78}$ Hver lífvera, eða lífsform - til dæmis fruma í mannslíkamanum - á sér pannig sitt umhverfi eða umheim. Pessi framsetning er í öllum aðalatriðum sambærileg við útskýringu á hugtakinu vist. Útfærsla von Uexkülls er aftur á móti talsvert önnur og byggir á pví að beina sjónum meira að pví sem nefna má starfrænt (e. functional) mikilvægi lífverunnar og umheims hennar. Pannig ákvarðast merking hluta og ferla í umheiminum útfrá starfrænu hlutverki peirra í tilveru viðkomandi lífvera. Мeð pessum hætti getur önnur lífvera í umheimi lífveru verið skilgreind sem fæða eða maki, eða sem yfirvofandi hætta; og dauðir hlutir - eins og steinn - sem staður til að búa á (til dæmis. umheimur margra fléttutegunda), eða sem áhald eða kannski vopn sem væri hægt að henda að einhverjum óvinveittum til að reka viðkomandi burt. Mikilvæg hlið kenningarinnar er að pessi starfræni tengslaveruleiki (e. functional relations) er oft gagnvirkur, og frægt er dæmi von Uexkülls um tengsl umheima mítils (e. tick) pegar peir lifa sníkjulífi á spendýrum. ${ }^{79}$ Pessu lýsir hann sem starfrænu hringferli (e. functional cycle) par sem parfir og lífsafkoma pessara ólíku lífvera tvinnast saman í samfelldu hringferli par sem gagnkvæm tilvist peirra mótar hinn starfræna veruleika sem verður til. Mikilvæg niðurstaða alls pessa er sú að umheimar lífvera og lífsforma eru margvíslegir, stundum sambærilegir en í öðrum tilfellum mjög ólíkir. En umheimarnir eru með ýmsum hætti samofnir og pví má skoða framvindu lífheimsins sem ógnarstórt starfrænt og

76 Ánægjulegt er að benda hér á nýlega íslenska grein: Bergljót Soffía Kristjánsdóttir og Benedikt Hjartarson, „Amoeba terricola. Inngangur höfunda“, og pýðingu á kafla úr riti Jakob von Uexküll, Umwelt und Innenwelt der Tiere (Skynheimur og innri heimur dýra), Ritið 2/2020, bls. 109-116. Takið eftir að hér er býska hugtakið Umwelt pýtt sem „skynheimur“ sem er að vissu marki sambærilegt við pýðinguna „umheimur" sem beitt er í pessari grein.

77 Jakob von Uexküll, A Forey in the Worlds of Animals and Humans, with: A Theory of meaning, Minneapolis: University of Minnesota Press, 2010.

78 Páll Skúlason, Umbverfing, Reykjavík: Háskólaútgáfan, 1998.

79 Jakob von Uexküll, A Forey in the Worlds of Animals and Humans, bls. 178. 
síbreytilegt samspil allra umheima sem til eru. Pessu líkti von Uexküll við tónverk par sem samræmd hljómkviðan endurspeglar hið merkingarlega samspil sem um ræðir á samræmdan hátt. ${ }^{80}$ Pessi framsetning er skyld hugtakinu vistkerfi, sem áður hefur verið rætt. En munurinn á umheimasinfóníu von Uexkülls og okkar hefðbundnu, oftast vélrænu, sýnar á vistkerfi er að fyrir honum var petta ekki einungis kerfi vélrænna tengsla, heldur fyrst og fremst heimur merkingar, og hann útfærði hugtakið Umwelt í sérstakri kenningu um tilkomu merkingar (e. theory of meaning). Pannig snýst merking hluta og ferla á hverjum tíma ekki eingöngu um efnislega gerð peirra, heldur frekar í pví hvernig túlkun á peim - tilurð merkingar - er háttað í peim umheimum sem pessir hlutir eða ferlar tilheyra hverju sinni, sem oft snýst um tilgang eða notagildi af einhverju tagi. Petta er auðvitað í hrópandi andstöðu við hina efnislegu sýn vélhyggjunnar, par sem athyglin beinist aðallega að orsökum og afleiðingum (beinum eða gagnkvæmum) í vélrænum tengslaheimi. Enda fer von Uexküll, eins og sumir aðrir samtímamenn hans ${ }^{81}$ ekki leynt með áhyggjur sínar af vélhyggju samtímans og að kenningar hans séu visst andsvar við hana: „Merking er sú pólstjarna sem líffræðin verður að notast við til að átta sig, ekki fátæklegar reglur um orsakakeðju sem einungis sér eitt skref áfram og eitt afturábak, sem veita enga innsýn í hinar miklu tengingar." ${ }^{\text {82 }}$

Раð ætti nú að vera augljóst með hvaða hætti petta fellur að kenningaheimi líftáknfræðinnar, par sem skynhæfni - í víðri merkingu - lífvera felst öðru fremur í að nema og túlka tákn sem leiðir síðan til merkingar eða skilnings á pví sem táknin vísa til, merkingar sem oft endurspeglar hvað hentar lífverunni eða lífkerfinu hverju sinni, allt frá smávægilegum upplýsingum yfir í lífsnauðsynlegar parfir. Pessi kenningaheimur er einungis

80 Samlíkingin kemur víða fram í Jakob von Uexküll, A Forey in the Worlds of Animals and Humans. Í nýlegum kenningum um proskaferli lífvera nota höfundar sambærilega líkingu við tónlist og einnig dans; sjá: Scott F. Gilbert og Jonathan Bard, „Formalizing theories of development. A fuge on the orderliness of change“, Towards a Theory of Development, ritstjórar Alessandro Minelli og Thomas Pradue, Oxford: Oxford University Press, 2014, bls. 129-143; og Susan Oyama, The Ontogeny of Information. Developmental Systems and Evolution, Durham: Duke University Press, 2. útgáfa, 2000, bls. 26.

81 Sjá umfjöllun í John Dupré og Daniel J. Nicholson, „A Manifesto for a Processual Philosophy of Biology“, bls. 3-45.

82 „Meaning is the polar star by which biology must orientate itself, not the impoverished rules of causality which can only see one step in front or behind and to which the great connections remain completely hidden. "Jakob von Uexküll, A Forey in the Worlds of Animals and Humans, bls. 160. 
að mjög takmörkuðu leyti tekinn með í pví sem við köllum lífvísindi í dag. Aftur á móti bendir margt til að petta sé að breytast eins og sjá má af nýlegum skrifum, ekki síst hins virta proskunarfræðings Scotts F. Gilberts. ${ }^{83}$ Samt sem áður er ljóst að orða- og hugtakanotkun líffræðinnar felur oft í sér tilvísun til táknfræði, án pess að höfundar átti sig almennilega á pví og nýti sér skýringargildi nálgunarinnar. ${ }^{84}$

Til að útskýra ofangreindar pælingar aðeins betur er gagnlegt að skoða samsvörun við kenningar Michael Polanyis (1891-1976). Hann leit svo á að í lífkerfum búi ákveðið form pekkingar sem ákvarðar og birtist í starfsemi peirra. Hér sé á ferðinni pekking ${ }^{85}$ sem er ekki sýnd (e. tacit knowledge), sem okkur er tamast að hugsa um í anda tvíhyggjunnar sem einhvers konar sjálfvirkni eða eitthvað ósjálfrátt, en hún birtist meðal annars í flókinni og markvissri starfsemi líkamans, svo sem öndun og blóðrás. Slík pekking getur lýst sér í alls kyns ómeðvituðum ferlum sem ekki eru tjáðir í hefðbundinni merkingu orðsins - ferlum sem búa að baki pví sem birtist í náttúrunni, til dæmis ógnarflókinni atburðarás taugakerfisins svo sem sjón. Hún getur líka birst við líkamlega reynslu af ýmsu tagi svo sem pegar við lærum sem börn að ganga, með öðrum orðum reynslu í umhverfinu eða umheiminum, og pegar við veitum pessari pekkingu vísvitandi athygli og proskum hana frekar, til dæmis lærum að spila á hljóðfæri, hjóla, aka bíl eða sitja hest. Í umfjöllun sinni um kenningar Polanyis bendir Wendy Wheeler ${ }^{86}$ á pað grundvallaratriði að hann lítur svo á að meðvituð eða vitsmunaleg pekking (e. abstract eða conceptual knowledge) og falin líkamleg pekking (e. tacit knowledge) séu upprunnar af sama meiði og byggðar á samræmdri rökskipan náttúrunnar, í andstöðu við pá aðgreiningu sálar og líkama, huga og efnis sem einkennir hefðbundna vélhyggju. Wheeler bendir

83 Scott F. Gilbert, „Ecological Developmental Biology. Interpreting Developmental Signs“, Biosemiotics 9/2016, bls. 51-60.

${ }^{84}$ Jesper Hoffmeyer, Biosemiotics. An Examination into the Signs of Life and the Life of Signs; og Claus Emmeche og Kalevi Kull, ritstjórar, Towards a Semiotic Biology. Life is the Action of Signs.

85 Hér mætti hugsa sér að nota orðið „vitund“ í stað „pekkingar“, samanber orðalag í síðari tilvísun neðanmáls nr. 104.

${ }^{86}$ Wendy Wheeler, The Whole Creature. Complexity, Biosemiotics and the Evolution of Culture. 
jafnframt á hversu hættulegt pað er pegar ákvarðanir eru teknar eingöngu á grundvelli meðvitaðrar pekkingar: „Aðgerðir (einkum pólítískar aðgerðir) sem byggja að mestu á óhlutbundinni hugsun, sem líta ekki til lifaðrar reynslu, pekkingar nærumhverfis og færni, eru ávallt, nánast samkvæmt skilgreiningu, hættulegar. ${ }^{\text {"87 }}$ Pessi niðurstaða er nátengd pví sem hér hefur verið lýst sem afsiðun náttúrunnar. Uppspretta gilda er að miklu leyti sniðgengin pegar vitsmunaleg og falin pekking eru aðskildar, sem augljóslega getur haft mikil áhrif á störf vísinda- og fræðafólks. Pannig vitum við í raun meira en við getum beinlínis tjáð okkur um (samanber orðið „falin“), en við leggjum ekki nægilega rækt við pessa staðreynd og setjum „meðvitaða“ vitund okkar í forsæti sem kyndilbera hlutlægni og vitsmuna gagnvart veruleikanum. Um er að ræða prönga mannhverfa nálgun sem sýnir athugunar- og virðingarleysi fyrir stórum hluta pess undraverks sem umheimur mannsins raunverulega felur í sér.

Rökin fyrir heildrænni sýn á pekkingu í anda Polanyis eiga mikið skylt við kenningar og útskýringar von Uexkülls og líftáknfræðinnar á lífheiminum, par sem tilkoma og eðli hinnar vistkerfislegu, líkamlegu og jafnframt hinnar „meðvituðu“ pekkingar er útskýrt í formi tákna og túlkunar peirra sem saman mynda merkingu og lýsa má sem samræmdu merkingar- eða rökkerfi heimsins. Heimssýn Polanyis gerði einmitt ráð fyrir samræmdu rökkerfi pekkingarinnar, og virðist eiga margt skylt við sýn Páls Skúlasonar um rökskipan heimsins. ${ }^{88}$ Saman endurspegla pessar nálganir heildræna sýn á náttúruna - í vissum skilningi sameiginlegt táknmál eða rökskipan - par sem vitsmunalegri stöðu mannsins er fundinn samastaður í víðtækum reynslu- og vitsmunaheimi peirra lífefna, forma og ferla sem hann er gerður úr eða órofa tengdur, og jafnframt er dregið úr sérstöðu meðvitaðrar pekkingar hans, pótt hún sé vissulega mikilvæg. ${ }^{89}$ Pessi niðurstaða á sér skýrar hliðstæður, til dæmis í kenningum um líkamlega gagnrýna hugsun sem nálgast og eykur pekkingu byggða á reynslu og upplifun (e. lived experience $)^{90}$ sem og pví sem Guðbjörg R. Jóhannesdóttir lýsir sem

87 „Actions (especially, perhaps, political actions) driven mainly by abstract thinking, which forget embodied experience, local knowledge and skilfulness, are always, almost by definition, dangerous." Sama rit, bls. 47.

88 Sama rit; Páll Skúlason, Merking og tilgangur, Reykjavík: Háskólaútgáfan, 2015.

89 Wendy Wheeler, The Whole Creature. Complexity, Biosemiotics and the Evolution of Culture bls. 74-79.

90 Donata Scholler og Sigríður Porgeirsdóttir, „Líkamleg gagnrýnin hugsun. Hvarfið að reynslunni og umbreytingamáttur pess, Hugur 30/2019, bls. 148-164. Pessi grein tengist viðamiklu rannsóknaverkefni um petta efni sem höfundar stýra ásamt 
innra landslagi líkamans. ${ }^{91}$ Vist- og próunarfræðingar eru nú í æ ríkari mæli að tileinka sér og aðlaga hugmyndir um mikilvægi pekkingar - eða upplýsinga - í lífkerfum. Nýlegt dæmi er grein líffræðinganna Richards Watsons og Eörs Szathmárys par sem sú pekkingaröflun eða lærdómur sem próunarferlar lífvera og tilurð líffræðilegrar fjölbreytni felur í sér er kynnt til sögunnar. ${ }^{92}$ Náttúruvísindin eru vissulega fær um að seilast út fyrir hið hamlandi afl vélrænnar hugsunar, en hér er mikið verk óunnið og mörg tækifæri til pekkingarsköpunar. ${ }^{93}$

\section{Merkingarbeimur og uppspretta gilda}

Auk mikilvægis kenninga von Uexkülls fyrir tilkomu og próun líftáknfræðinnar höfðu pær áhrif á suma heimspekinga, ekki síst fyrirbærafræðinga eins og Martin Heidegger (1889-1976) og Maurice Merleau-Ponty (19081961). ${ }^{94}$ Pannig má finna hliðstæðu í nálgunum við pað sem hér er fjallað um til dæmis í greinum Guðbjargar R. Jóhannesdóttur, Ólafs Páls Jónssonar og Björns Porsteinssonar í bókinni Náttúran i ljósaskiptunum, en pau byggja pælingar sínar að allmiklu leyti á kenningum Merleau-Pontys og ræða hvert á sinn hátt áhugaverðar útfærslur á eðli og merkingarbærni pess tengslaveruleika og skynheims sem hér um ræðir. ${ }^{95}$

Páll Skúlason byggir kenningu sína um merkingarheim talsvert á heimspeki Heideggers, og par svífur hugmyndin um umheim lífvera (Umwelt)

Birni Porsteinssyni heimspekingi, sjá: www.ect.hi.is. Sjá líka viðtal á Hugrás, vefriti Hugvísindasviðs Háskóla Íslands; Guðmundur Hörður Guðmundsson, „Hugsað með líkamanum“, Hugrás, vefrit Hugvísindasviłs Háskóla Íslands, 8. mars 2019, sótt 7. desember 2020 af: http://hugras.is/2019/03/hugsad-med-likamanum/.

91 Guðbjörg R. Jóhannesdóttir, „Innra landslag líkamans. Fyrirbærafræði hugsunar“, Hugur 30/2019, bls. 38-52.

92 Richard A. Watson og Eörs Szathmáry, „How Can Evolution Learn?“, Trends in Ecology and Evolution 2/2016, bls. 147-157.

93 Pessi grein sýnir sambland af hefðbundinni framsetningu liffræðinga og viðleitni til að tileinka sér pá útvíkkun sem greinilega er að eiga sér stað í pessum fræðum: Skúli Skúlason og fleiri, „A way forward with eco evo devo. An extended theory of resource polymorphism with postglacial fishes as model systems“, bls. 1786 - 1808 .

94 Kenningar von Uexkülls og áhrif peirra eru ræddar ítarlega í Carlo Brentari, fakob von Uexkuill. The Discovery of the Umwelt between Biosemiotics and Theoretical Biology, Dordrecht: Springer, 2015.

95 Ólafur Páll Jónsson, „Maður og náttúra“, bls. 13-33; Björn Porsteinsson, „Flókinn“, Náttúran í ljósaskiptunum, ritstjóri Björn Porsteinsson, Reykjavík: Heimspekistofnun - Háskólaútgáfan, 2016, bls. 75-92; Guðbjörg R. Jóhannesdóttir, „Vá! - Undrun, fegurð og ægifegurð í upplifun af íslenskri náttúru“, bls. 143-168. 
yfir vötnum. ${ }^{96}$ Pannig fæðist merkingin samhliða notagildi hluta og ferla í slíkum tengslaheimi veruleikans alls, og skilaboð og tákn eru forsenda túlkunarinnar hverju sinni. Parna bendir Páll á hugtök Heideggers um tilvísanakerfi og tiltækileika hlutanna, að heimurinn sé í raun heild tilvísanakerfa, sem í túlkun Páls eru merkingarkerfi. Í pessu sambandi er íslenskan býsna gagnleg. Hugtakið merking er nefnilega fullkomlega gagnsætt par sem pað vísar til afmörkunar einhvers, að setja mörk eða merkja. Í stuttu máli, felur pað í sér mismun eða breytileika hlutanna; afmörkun felur í sér að vera aðskilið eða ólíkt einhverju öðru. Breytileikinn er sem sagt samofinn og í senn forsenda og birtingarmynd merkingarinnar og par með pess notagildis sem hún hefur. ${ }^{97}$ Mannfræðingurinn og heimspekingurinn Gregory Bateson (1904-1980) nálgaðist tengsla- og merkingarveruleika náttúrunnar einmitt á forsendum hugtaksins mismunur eða breytileiki (e. difference eða diversity), og komst að peirri niðurstöðu að allar upplýsingar eða pekking grundvallist á mismun sem skiptir máli, pegar hann sagði: „Upplýsingar felast í mismun sem skiptir máli. “98 Hann bendir á að í tilkomu og varanleika slíkrar pekkingar - á forsendum breytileikans - og peim tækifærum sem hún gefur, felist ákveðið form hugsunar í náttúrunni; enda heitir sú bóka hans sem hér er vitnað til, Mind and Nature, a necessary unity. ${ }^{99}$

Í ljósi ofangreindrar umfjöllunar ætti að vera nokkuð ljóst að gildi, par með talin siðferðileg gildi, geta átt samskonar uppruna og merking. Pannig kemst Páll að peirri niðurstöðu að gildi séu ákveðin tegund merkingar. ${ }^{100}$ Tilkoma gilda í menningunni, í umheimi annarra dýrategunda eða í vistkerfi er samkvæmt pessu af sama meiði, og hér er sú tilgáta sett fram að gildin fæðist pegar gagnsemi ákveðinnar merkingar - eða bekkingar - öðlast varanleika, verður hluti af veruleikanum um marktæka stund eða öðlist birtingamynd sem eykur slíkan varanleika. Рað má pví hugsa sér að tilkoma gilda í tengslavef tilverunnar birtist meðal annars í fagurferðilegum upplifunum okkar í náttúrunni eins og Guðbjörg R. Jóhannsdóttir og Edda Waage ræða um í grein sinni, „Að fanga fagurferðilegt gildi lands-

96 Páll Skúlason, Merking og tilgangur, bls. 43-55.

97 Sama rit, bls. 75-77 og bls. 83.

98 „Information consists of differences that make a difference“. Gregory Bateson, Mind and Nature, a necessary unity, Glasgow: Fontana/Collins, 1979, bls. 110.

99 Sama rit. Áðurnefnd kenning um pekkingu í próunarferlum lífkerfa er byggð á sambærilegum pælingum og Batesons, sjá Richard A. Watson og Eörs Szathmáry, „How Can Evolution Learn?“, bls. 147-157.

${ }^{100}$ Páll Skúlason, Merking og tilgangur, bls. 73-91, sjá til dæmis útfærslur bls. 78-80. 
lags. Próun aðferðafræði í rannsóknum við mat á landslagi“101, eða í afstöðu og samböndum okkar við önnur náttúrufyrirbæri sem byggja á vináttu, ást og lotningu, eins og náttúruheimspekingurinn Henry David Thoreau lagði áherslu á, og á sér hliðstæður í náttúrusiðfræði Aldos Leopolds og J. Birds Callicotts sem gerir ráð fyrir manninum sem órofa hluta siðvæddra vistkerfa. ${ }^{102}$ Orðið „siðvæddra“ vísar til pess að hér sé vikið af vegi peirrar afsiðunar náttúrunnar sem áður var skilgreind og rædd. Мeð öðrum orðum gerir siðvæðing náttúrunnar ráð fyrir að öll gildi hennar séu virt, en ekki einungis pau sem varða sértæka hagsmuni mannsins.

Eðli og mikilvægi siðferðilegra gilda náttúrunnar sést best í peirri starfsemi, ákvarðanatöku og hegðun, sem á peim er byggð, en aðeins ef peim er veitt athygli, og sýnd umhyggja, auðmýkt og virðing. Frá sjónarhóli mannsins byggist slík nálgun á pví að viðurkenna takmörk sín, bera virðingu fyrir eigin umheimi og peirri pekkingu sem hann felur í sér, en ekki síður umheimum annarra lífvera og lífkerfa sem eru okkur oft að miklu huldir - pó svo að tilvera okkar sé peim háð - og saman myndi peir pá tengslaheild sem við erum hluti af. Náttúrusiðfræði Páls ber sterkan keim af pessari hugsun, maðurinn er órofa hluti náttúrunnar, náttúru sem einkennist og er að miklu leyti knúin áfram af gagnkvæmri merkingarbærni hluta og ferla, merkingu sem oftar en ekki endurspeglar gildi og verðmæti, sem ákveða starfsemi lífvera og lífkerfa, gera peim kleift að vera til og proskast. Pannig segir hann: „[...]að öfl náttúrunar eru okkur ótæmandi uppspretta gilda og verðmæta“, ${ }^{103}$ og rætur pessarar einföldu yfirlýsingar má sjá í samræmdri sýn hans á menningu og náttúru:

Og á milli hinna samfélagslegu og náttúrulegu kerfa liggja augljósir og leyndir bræðir sem vekja meðal annars upp pá spurningu hvort pessi kerfi séu ekki af sama toga spunnin pegar öll kurl koma til grafar. Раð séu engin skörp skil á milli menningar og

${ }^{101}$ Guðbjörg R. Jóhannesdóttir, „Vá! - Undrun, fegurð og ægifegurð í upplifun af íslenskri náttúru“, bls. 143-168; Edda R. H. Waage og Guðbjörg R. Jóhannesdóttir, „Að fanga fagurferðilegt gildi landslags. Próun aðferðafræði í rannsóknum við mat á landslagi“, Ritið 3/2019, bls. 95-130.

102 Sjá góða umfjöllun um pessar kenningar í: Jón Ásgeir Kalmansson, „„,Hið panda segl, hinn rennandi lækur ...““, bls. 69-94 og Ólafur Páll Jónsson, „Maður og náttúra“, bls. 13-33.

${ }^{103}$ Páll Skúlason, Merking og tilgangur, bls. 88; ég bendi líka á ítarlegar útfærslur hans í ritgerðasafninu Náttúrupelingar og pá hvað helst fyrstu prjár ritgerðirnar: „Hugleiðingar við Öskju. Um samband manns og náttúru“, „Náttúran í andlegum skilningi“" og „Andi og óbyggðir“. 
náttúru eða andlegs lífs og líkamlegs. Pá er freistandi að álykta að í náttúrunni megi finna gildakerfi sem eru hliðstæð peim sem sérveran myndar í umhverfi sínu og bindur við sjálfa sig. Og pá vaknar óhjákvæmilega sú spurning hvort í lífríkinu búi ekki einhvers konar vitund pótt öðruvísi sé en sú vitund sem býr í sérverunni sem er að verki í okkur sjálfum. ${ }^{104}$

Páll lýsir pví hvernig tengsl mannsins við gildin í náttúrunni eru forsenda proska hans og skilnings sem hann byrfti að rækta og nýta betur og yfirvega við ákvarðanatöku um gjörðir sínar og framkomu, til dæmis pegar huga skuli að virkjanamálum eða takast á við glímuna við loftslagsbreytingar. ${ }^{105}$ Að sama skapi bendir Roope Karoneen á hvernig kenningar Polanyis um falda pekkingu, í bland við ferlaheimspeki, hjálpi til við að sameina mann og náttúru og með hvaða hætti sú afstaða getur leitt til bættrar stefnumótunar og ákvarðanatöku samfélaga gagnvart umhverfisvanda samtímans. ${ }^{106}$

\section{Lokaorð}

Hér hefur verið bent á ákveðnar kenningar og pælingar í líffræði og heimspeki sem eiga athygliverðan samhljóm og geta mögulega verið okkur leiðarvísir að pví að siðvæða náttúruna að nýju, par með talið að blása lífi í lífvísindin í orðsins fyllstu merkinu, líkt og ritstjórarnir Brian G. Hennig og Adam C. Scarfe ítreka með undirtitli bókar sinnar Putting Life Back to Biology ${ }^{107} \mathrm{Niðurstaða} \mathrm{pessarar} \mathrm{greinar} \mathrm{er} \mathrm{í} \mathrm{megindráttum} \mathrm{sú} \mathrm{að} \mathrm{pau} \mathrm{gildi,} \mathrm{sem}$ birtast í starfsemi lífveranna, hvað pær gera, og hvað verður um pær, eigi sér að miklu leyti uppsprettu í tengslaheimi tákna og merkingar. Ákvarðanir okkar og annarra lífvera eru byggðar á margvíslegri pekkingu sem býr í merkingarheiminum. Ofangreind niðurstaða felur í sér að eðli tengsla í mannheimi - menningin - er hluti af stærri tengslaheimi náttúrunnar, til dæmis eru tungumál í grunneðli sínu af sama tagi og önnur táknfræði í náttúrunni. Fjölbreytileikinn í öllu pessu er vissulega óendanlegur, tákn og merking eru margvísleg og oft mjög óstöðug. Samt sem áður eru lífkerfin

${ }^{104}$ Páll Skúlason, Merking og tilgangur, bls. 114. Skyldleiki pessarar framsetningar við áourræddar kenningar um falda pekkingu í náttúrunni, líkamlega hugsun og hugsun í náttúrunni er ótvíræður.

${ }^{105}$ Páll Skúlason, Náttúrupalingar, bls. 42 og 49.

${ }^{106}$ Roope O. Karoneen, „Reframing tacit human-nature relations. An inquiry into process philosophy and the philosophy of Michael Polanyi“, bls. 179-201.

${ }^{107}$ Brian G. Hennig og Adam C. Scarfe, ritstjórar, Beyond Mechanisms. 
að miklu leyti sambærileg í grunngerð sinni, og ferlar - eins og proski einstakra lífvera og próun tegundanna - mynda skiljanlegt, röklegt samhengi. Hér ríkir ekki óreiða - pað er ákveðin „regla“ á hlutunum í náttúrunni og framvindu peirra. Framvindan í lífi einstaklings eða í próun tegundanna, samkvæmt peirri skapandi ferlahyggju sem hér hefur verið kynnt, byggist á pví að framtíðin er stanslaust sköpunarferli. Par spilar saman ákveðinn fyrirsjáanleiki eða farvegur sem fortíðin endurspeglar - og óvæntar aðstæður eða verkefni sem oftar en ekki verða efniviður breytinga frá farvegi hins liðna. Heimur tengsla, tákna og merkingar, hugsun og ákvarðanataka náttúrunnar eru hér í lykilhlutverki. Afar mikilvægur hluti pessa, og oft mjög stöðugur, er sá hluti merkingarinnar sem tengist uppsprettu siðferðilegra gilda. Dæmi um birtingarmynd slíkra verðmæta er að ákveðin líkamsstarfsemi geti yfirleitt átt sér stað, eins og sláttur hjartans; að ákveðinn stofn dýra geti aflað sér peirrar fæðu sem er honum lífsnauðsynleg; að ákveðin próunarleg aðlögun stofns að breyttu umhverfi (til dæmis vegna loftslagsbreytinga) geti átt sér stað; eða að við mennirnir getum tekið skynsamlegar ákvarðanir í umgengni okkar og nýtingu náttúruauðlinda. Af pví sem áður hefur verið sagt má sjá að grunngildi að baki alls pessa er mismunur eða fjölbreytni sem Gregory Bateson byggir alla sína kenningu á, og vegur einnig pungt í hugmyndum Páls Skúlasonar. Hér er að minnsta kosti ein skýring pess hvers vegna fjölbreytnihugtakið er svona mikilvægt í allri okkar samfélagsgerð og áætlunum til dæmis um verndun umhverfisins, pótt pessi grunneiginleiki hugtaksins sé ekki endilega oft í umræðunni. Höfum í huga að án fjölbreytni eru engir valkostir, hvorki við framvindu mannlífsins, ákvarðanatöku og stefnumótun, né í líffræðilegri próun stofna og tegunda.

Hin ríkjandi vélræna nálgun á náttúruna ræður einungis við að skýra hluta kerfa og framvindu hennar. Vandinn hér er fyrst og fremst hin statíska sýn sem fylgir henni oft. Tákn, skilaboð og viðbrögð við peim eru skoðuð í nánu samhengi við efnislega gerð peirra eininga sem í hlut eiga en túlkun, merking og hugsun fá minni athygli, og birtast gjarnan sem dularfullur og oútskýrður fylgifiskur hinna vélrænu og efnislegu tengsla. Aðskilnaður manns og náttúru er hér í fyrirrúmi.

Við mennirnir - ekki síst vísindafólkið - erum vissulega ófullkomin og breysk, en pað er jafnframt styrkur okkar, pví við stöndum sem hugsandi verur frammi fyrir valkostum í samfélagi við tengslaveruleika allrar náttúrunnar, og líf okkar og framtíðarafkoma sem tegundar ákvarðast af skapandi framgöngu (e. creative advance) hverju sinni. Í slíkri framgöngu purfum við 
að setja vélhyggjuna skör neðar, láta af pröngri sýn á skammtíma hagsmuni okkar, og leggja mun meiri rækt við að skilja og beita peim gildum sem spretta af náttúrunni í allri sinni dýrð og breytileika. Til að finna og skilja betur tilkomu og eðli pessara gilda er mikilvægt að beina athygli okkar og lífsháttum á hverjum tíma mun meira að pátttöku okkar, skynvísi og reynslupekkingu, í ferlaheimi fjölbreyttar náttúrunnar. Sömuleiðis purfum við að hjálpa öðrum við petta verkefni, meðal annars með fræðslu og pjálfun. Fræðaheimurinn parf að styðja dyggilega við pessa viðleitni með rannsóknum og agaðri hugtakasköpun og greiningu, sem gerir meðal annars kleift að nota tungumál okkar á pann hátt að eiga megi gefandi samskipti um pá hugarfarsbreytingu sem petta verkefni snýst um, og leiðsegir hvernig nýta megi pekkingu á pessu sviði markvisst til að greiða pann farveg sem athyglin, reynslan og skynvísin parfnast í pessu umfangsmikla verkefni.

Forsendur ákvarðana okkar eiga sér rætur og alls konar hliðstæður í kerfum og ferlum náttúrunnar sem við erum órofa hluti af. Leiðin til betra lífs, pó kannski ekki algjörrar syndaaflausnar, er að haga öllu lífi okkar í samræmi við pessa staðreynd. Мeð öðrum orðum, skynjun, viðurkenning og virðing fyrir fjölbreytni og gildum náttúrunnar ætti að vera upphaf og leiðarstef í mögulegri vegferð okkar úr peim ógöngum sem við höfum lent í og lýst var í upphafi greinarinnar. Hér reynir á hvers kyns lífshætti, miðlun, umræðu, fræðastörf, fræðslu og skipulega menntun, sem og stjórnmál og stefnumótanir. Pessir pættir samfélags okkar verða að tileinka sér svona nálgun í mun ríkari mæli, og nú megum við engan tíma missa. Umræða og aðgerðir verða að haldast í hendur. ${ }^{108}$

${ }^{108}$ Höfundur pakkar Sólrúnu Harðardóttur, Ásdísi Rósu Magnúsdóttur, Magnúsi Skúlasyni, Viðari Hreinssyni, Ármanni Halldórssyni og tveimur ritrýnum fyrir yfirlestur, mjög góðar ábendingar og tillögur. Einnig vill hann pakka Steven Cronshaw og Guðbjörgu R. Jóhannesdóttur fyrir góðar ábendingar um heimildir og túlkun hugmynda. Pá vill höfundur pakka peim fjölmörgu sem hann hefur rætt við og lært af við mótun peirra hugmynda sem fram koma í greininni. Að lokum vill höfundur pakka tækifærið að taka pátt í málstofunni um syndina, sem petta hefti byggir á og pað tækifæri að skrifa pessa grein í framhaldinu. Aðfararorð Louis Armstrong að lagi hans What a Wonderful World, og að sjálfsögðu skilaboð verksins, eru að mati höfundar viðeigandi veganesti í lokin, Louis Armstrong, „What a Wonderful World“, Youtube, 13. september 2011, sótt 7. desember 2020 af: https://www.youtube.com/ watch? $=2 \mathrm{nGKqH} 26 \mathrm{xlg}$. 


\section{ÚT D RÁTTUR}

Eins og kunnugt er blasir við okkur alvarlegur umhverfisvandi sem ógnar lífi á jörðinni. Framferði mannsins á par stærstan hlut að máli. Á líkingamáli má segja að orðið hafi misgengi milli viðhorfa okkar, siðferðis og lífshátta annars vegar og náttúrunnar hins vegar. Maðurinn hefur 1 krafti hraðvaxandi tæknilegrar getu sinnar og valds sagt sig úr lögum við vistkerfi jarðarinnar og farið að drottna yfir pví og nýta sér á mjög óvarlegan hátt. Með pví vinnur hann gegn viðgangi náttúrunnar sem hann er pó órjúfanlega samofinn. Í pessu birtist áðurnefnt misgengi. Í ritgerð pessari er leitast við að greina og leita skilnings á pessari stöðu, orsökum hennar og afleiðingum sem og úrræðum við vandanum. Nálgunin er pverfagleg og niðurstöður vísinda og fræða eru skoðaðar samhliða áhrifum siðmenningar og gildismats. Í pessu skyni er stuðst við leiðir líffræði og heimspeki, ekki síst líftáknfræði og siðfræði, og bent á órofa samspil pessara greina. Niðurstaðan er sú að menningu okkar, pekkingu og vitund verði að samstilla betur hinni náttúrulegu skipan, í págu fjölbreytni og skapandi framvindu lífs á jörðinni. Í ferlum náttúrunnar liggi rætur peirra gilda og merkingar sem gera tilveru okkar og annarra lífvera í senn mögulega og verðuga. Að peim rótum parf maðurinn að hlúa mun betur og tengjast; víkja af vegi drottnunar gagnvart náttúrunni og laga viðhorf og lifnaðarhætti sína að peim breytta veruleika.

Lykilorð: umhverfisvá, gildi náttúrunnar, líftáknfræði, fjölbreytni, sjálfbærni

\section{A B S T R A C T \\ Is sin natural? \\ The importance of world views and the source of values}

As is well known we are currently facing a serious environmental challenge that threatens life on Earth. Human activity is the main culprit. To use an analogy it can be said that a rift has been created between our views, our morality, and way of life, on the one hand, and nature on the other. Empowered through its expanding technological prowess and power humanity has cut loose from the Earth's ecological systems, lording over them and utilising in a very careless manner. Thus humanity opposes the processes of nature; processes of which it nevertheless is an integral part. Thus the aforementioned rift is formed. In this essay an attempt is made to analyse and look for an understanding of this predicament, its causes and consequences and potential solutions. The approach is interdisciplinary and the conclusions of science and scholarship are viewed alongside the impact of civilisation and value 


\section{SKÚLI SKÚLASON}

judgements. To this end the methods of biology and philosophy are employed, not least biosemiotics and ethics, and the inextricable connection of these disciplines is pointed out. The conclusion is that our culture, knowledge and consciousness must be attuned better to the natural order, to revive the diversity and creative progress of life on Earth. The roots of the values and meaning that make the existence of man, and indeed all organisms, possible and worthy lie in the processes of nature. These roots must be tended by humanity and connections restored; to abandon the path of lording over nature and align our views and ways of life to such a changed reality.

Keywords: environmental threat, value of nature, biosemiotics, diversity, sustainability

\section{Skúli Skúlason}

Prófessor í vist- og próunarfræði við Háskólann á Hólum

og Náttúruminjasafn Íslands

Fiskeldis- og fiskalíffræðideild

Háskólinn á Hólum

Hólum í Hjaltadal

IS-551 Sauðárkróki, Ísland

Suðurlandsbraut 24

IS-108 Reykjavík, Ísland

skuli@holar.is 